Prepared in cooperation with the Virginia Department of Environmental Quality

\title{
A Conceptual Framework and Monitoring Strategy for Movement of Saltwater in the Coastal Plain Aquifer System of Virginia
}

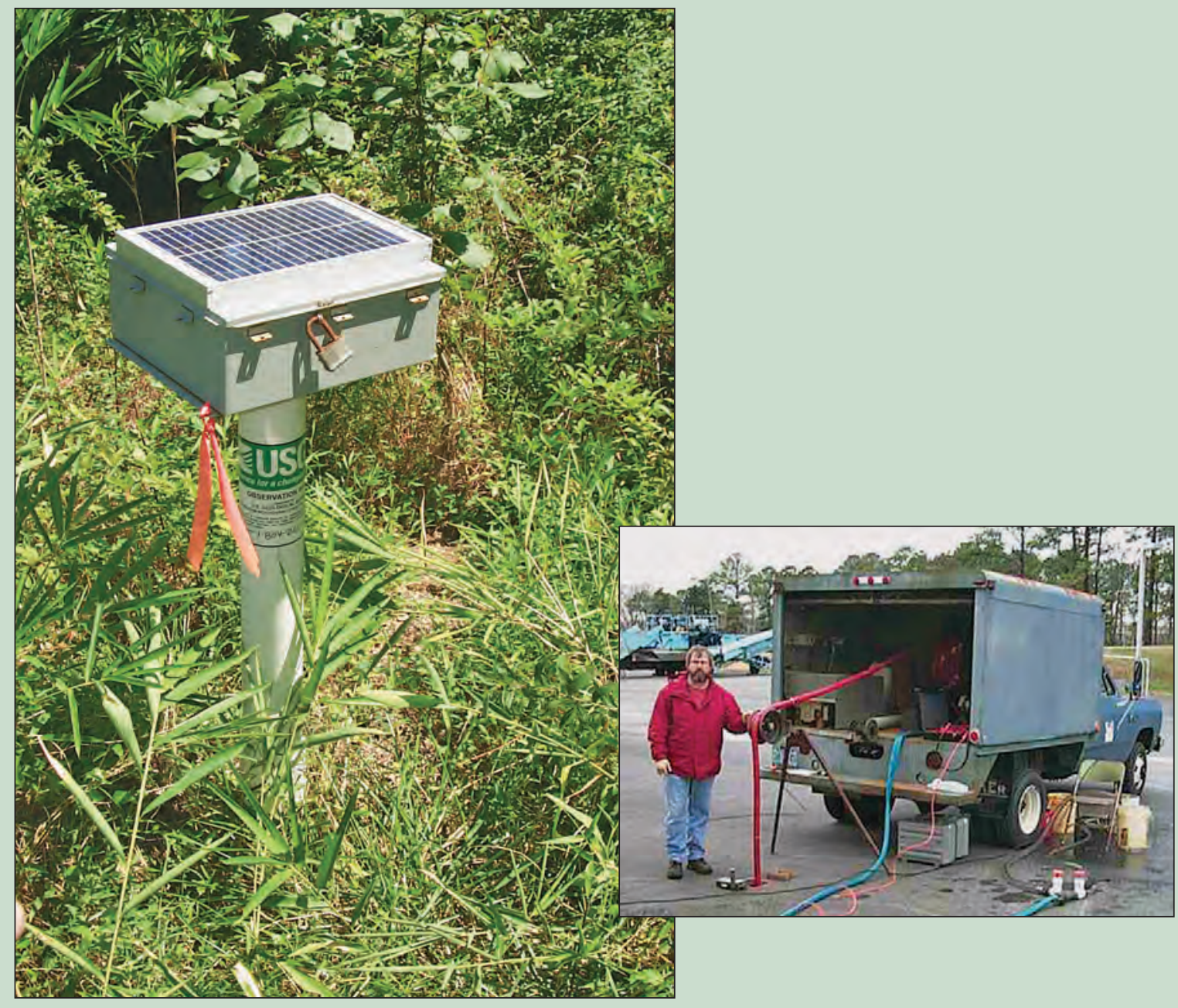

Scientific Investigations Report 2015-5117

U.S. Department of the Interior

U.S. Geological Survey 
Cover. Left, observation well 62C 5 SOW 093 completed in the unconfined surficial aquifer in the city of Virginia Beach, Virginia. Well depth is 65 feet, and depth to water has averaged 5 feet over the past 10 years. A groundwater chemical quality sample collected on July 30 , 2013, had a chloride concentration of 58.7 milligrams per liter. The well is included in the U.S. Geological Survey real-time groundwaterlevel network available at http://waterdata.usgs.gov/nwis/dv?referred_module=sw\&site_no=364504076031301. Additional information on observation well 62C 5 SOW 093 is available at http://groundwaterwatch.usgs.gov/AWLSites.asp?S=364504076031301. Photograph by Roger M. Moberg, U.S. Geological Survey.

Right, collection of a groundwater chemical quality sample on March 15, 2001, from observation well $61 \mathrm{C} 1$ completed in the confined Potomac aquifer in the city of Norfolk, Virginia. The wellhead is finished below the level of the parking lot. Well depth is 970 feet, and depth to water has declined from about 15 to 85 feet over the past 47 years. From the time of this sample to another sample collected on July 29, 2010, groundwater chloride concentration increased from 1,150 to 1,210 milligrams per liter. More information on observation well 61C 1 is available at http://groundwaterwatch.usgs.gov/AWLSites.asp?S=365223076122101. Photograph by Karl M. Dydak, U.S. Geological Survey. 


\section{A Conceptual Framework and Monitoring Strategy for Movement of Saltwater in the Coastal Plain Aquifer System of Virginia}

By E. Randolph McFarland

Prepared in cooperation with the Virginia Department of Environmental Quality

Scientific Investigations Report 2015-5117 


\title{
U.S. Department of the Interior SALLY JEWELL, Secretary
}

\section{U.S. Geological Survey \\ Suzette M. Kimball, Acting Director}

\author{
U.S. Geological Survey, Reston, Virginia: 2015
}

For more information on the USGS - the Federal source for science about the Earth, its natural and living resources, natural hazards, and the environment—visit http://www.usgs.gov or call 1-888-ASK-USGS.

For an overview of USGS information products, including maps, imagery, and publications, visit http://www.usgs.gov/pubprod/.

Any use of trade, firm, or product names is for descriptive purposes only and does not imply endorsement by the U.S. Government.

Although this information product, for the most part, is in the public domain, it also may contain copyrighted materials as noted in the text. Permission to reproduce copyrighted items must be secured from the copyright owner.

Suggested citation:

McFarland, E.R., 2015, A conceptual framework and monitoring strategy for movement of saltwater in the Coastal Plain aquifer system of Virginia: U.S. Geological Survey Scientific Investigations Report 2015-5117, 30 p., 1 pl., http://dx.doi.org/10.3133/sir20155117.

ISSN 2328-031X (print)

ISSN 2328-0328 (online)

ISBN 978-1-4113-3970-5 


\section{Contents}

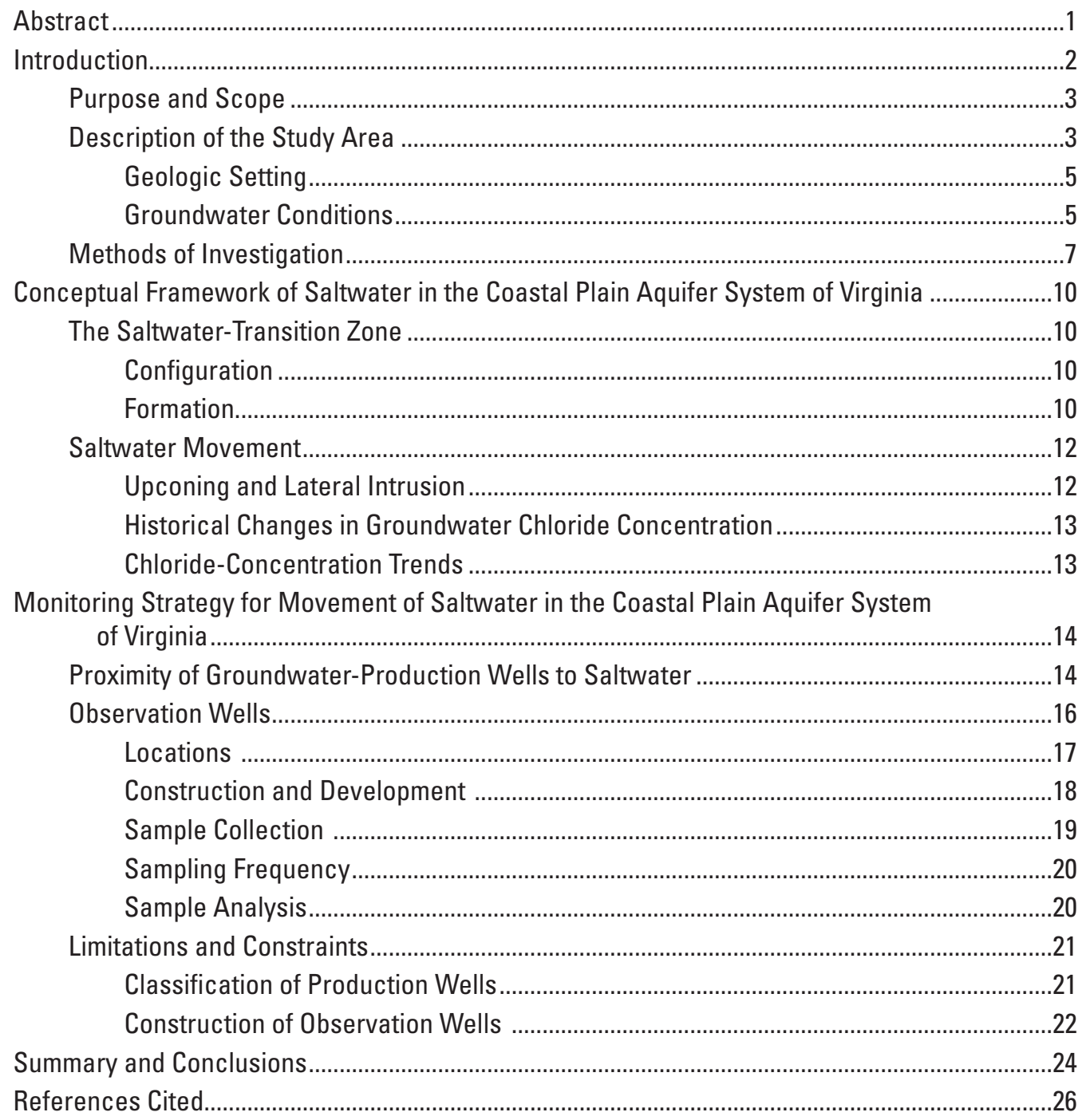




\section{Digital Storage Media}

[CD-ROM in pocket attached to back cover. Also available for downloading from http://dx.doi.org/10.3133/sir20155117.]

Attachment 1. Excel file containing groundwater-production wells, vertical positions, and lateral distances and directions relative to chloride iso-concentration surfaces, and projected locations of lateral-intrusion observation wells

\section{Plate}

[In pocket attached to back cover. Also available for downloading from http://dx.doi.org/ 10.3133/sir20155117.]

1. Locations of groundwater-production wells, projected locations of lateral intrusion observation wells, and the configuration of the 250-milligrams-per-liter chloride iso-concentration surface in the Coastal Plain of Virginia

\section{Figures}

1. Map showing locations of groundwater-production wells, projected locations of lateral-intrusion observation wells, and the configuration of the 250-milligrams-per-liter chloride iso-concentration surface

2. Generalized hydrogeologic section and directions of predevelopment groundwater flow in the Virginia Coastal Plain

3. Map showing simulated hydraulic head during 2003 and groundwater total ion concentration in the Potomac aquifer.

4. Diagram showing projection of lateral intrusion observation-well location from groundwater-production well.

5. Diagrams showing movement of saltwater.

6. Diagram showing generalized temporal relations among groundwater chloride concentrations, water levels, and withdrawals

7. Diagram showing generalized spatial relations of groundwater-production wells to chloride iso-concentration surfaces.

8. Diagram showing generalized spatial relations among groundwaterproduction wells, observation wells, and the 250-milligrams-per-liter chloride iso-concentration surface

9. Diagram showing pump placement and responses of observation wells to purging

10. Diagram showing adjustments to observation-well depths relative to positions within the aquifer system

11. Diagram showing generalized spatial relations of observation wells to multiple neighboring groundwater-production wells.....

\section{Table}

1. Groundwater-production wells, vertical positions and lateral distances and directions relative to chloride iso-concentration surfaces, and projected locations of lateral intrusion observation wells in the Coastal Plain of Virginia 


\section{Conversion Factors}

Inch/Pound to SI

\begin{tabular}{lcl}
\hline \multicolumn{1}{c}{ Multiply } & By & \multicolumn{1}{c}{ To obtain } \\
\hline foot $(\mathrm{ft})$ & Length & meter $(\mathrm{m})$ \\
mile $(\mathrm{mi})$ & 0.3048 & kilometer $(\mathrm{km})$ \\
\hline & 1.609 & \\
\hline square mile $\left(\mathrm{mi}^{2}\right)$ & Area & hectare $(\mathrm{ha})$ \\
square mile $\left(\mathrm{mi}^{2}\right)$ & 259.0 & square $\mathrm{kilometer}\left(\mathrm{km}^{2}\right)$ \\
\hline & 2.590 & \\
\hline feet per year $(\mathrm{ft} / \mathrm{yr})$ & Flow rate & meters per year $(\mathrm{m} / \mathrm{yr})$ \\
gallons per month $(\mathrm{gal} / \mathrm{mo})$ & 0.3048 & liters per month $(\mathrm{L} / \mathrm{mo})$ \\
million gallons per day $(\mathrm{Mgal} / \mathrm{d})$ & 3.785 & cubic meters per second $\left(\mathrm{m}^{3} / \mathrm{s}\right)$ \\
\hline
\end{tabular}

\section{Supplemental Information}

Concentrations of chemical constituents in water are given in milligrams per liter (mg/L).

\section{Datums}

Vertical coordinate information is referenced to the National Geodetic Vertical Datum of 1929 (NGVD 29).

Horizontal coordinate information is referenced to the North American Datum of 1927 (NAD 27).

Altitude, as used in this report, refers to distance above or below the vertical datum.

\section{Abbreviations}

GIS geographic information system

LOWESS Locally Weighted Scatterplot Smoothing

RASA Regional Aquifer-System Analysis

SMCL secondary maximum contaminant level

USGS U.S. Geological Survey

VA DEO Virginia Department of Environmental Quality 


\section{Acknowledgments}

This study was supported by the Virginia Department of Environmental Quality (VA DEO). Special thanks for program planning go to Scott Kudlas, Craig Nichol, Scott Bruce, and Mary Ann Massie of VA DEO. Thanks also are extended to the many drillers and owners of water-supply wells, who have provided well data from across the Virginia Coastal Plain. The scientific integrity of this report was aided greatly from reviews by Bruce Campbell of the U.S. Geological Survey (USGS) South Carolina Water Science Center, and Emmanuel Charles of the USGS New Jersey Water Science Center. Editorial and graphical quality of the report was aided greatly by Rebekah Davis and Caryl Wipperfurth of the USGS Science Publishing Network.

This project has been funded in part by the U.S. Environmental Protection Agency (EPA) under assistance agreement BG-98392505-1 to the VA DE0. The contents of this document do not necessarily reflect the views and policies of the EPA, nor does the EPA endorse trade names or recommend the use of commercial products mentioned in this document. 


\title{
A Conceptual Framework and Monitoring Strategy for Movement of Saltwater in the Coastal Plain Aquifer System of Virginia
}

\author{
By E. Randolph McFarland
}

\begin{abstract}
A conceptual framework synthesizes previous studies to provide an understanding of conditions, processes, and relations of saltwater to groundwater withdrawal in the Virginia Coastal Plain aquifer system. A strategy for monitoring saltwater movement is based on spatial relations between the saltwater-transition zone and 612 groundwater-production wells that were regulated during 2013 by the Virginia Department of Environmental Quality. The vertical position and lateral distance and direction of the bottom of each production well's screened interval was calculated relative to previously published groundwater chloride iso-concentration surfaces. Spatial analysis identified 81 production wells completed in the Yorktown-Eastover and Potomac aquifers that are positioned in closest proximity to the 250-milligrams-per-liter chloride surface, and from which chloride concentrations are most likely to increase above the U.S. Environmental Protection Agency's 250-milligrams-per-liter secondary maximum-contaminant level. Observation wells are specified to distinguish vertical upconing from lateral intrusion among individual production wells. To monitor upconing, an observation well is to be collocated with each production well and completed at about the altitude of the 250-milligrams-per-liter chloride isoconcentration surface. To monitor lateral intrusion, a potential location of an observation well is projected from the bottom of each production well's screened interval, in the lateral direction to the underlying chloride surface to a distance of 1 mile.

Monitoring potential withdrawal-induced movement of saltwater in the Virginia Coastal Plain aquifer system is needed to detect increases in chloride concentration before groundwater-production wells become contaminated. An investigation was undertaken during 2014 by the U.S. Geological Survey in cooperation with the Virginia Department of Environmental Quality, to provide a sound scientific understanding of saltwater movement and guidance to implement a monitoring program. Previous studies have theorized that the saltwater
\end{abstract}

originated primarily from seawater repeatedly emplaced within aquifer sediments during the past about 65 million years. Subsequent flushing by fresh groundwater has been impeded across sediments filling the Chesapeake Bay impact crater. The resulting saltwater-transition zone has been mapped to exhibit a warped and steeply mounded dome shape about centered on the impact crater, and flanked by a nearly level and shallow plateau shape to the southeast. Groundwater chloride concentrations have historically fluctuated during periods of weeks to months, probably as a result of localized vertical upconing beneath individual production wells. Lateral intrusion takes several decades or more to horizontally displace groundwater across distances of about 1 mile toward production wells. Upconing is relatively immediate, but reversible, whereas lateral intrusion under the regionally landward hydraulic gradient may slowly, but permanently reposition the saltwatertransition zone. Upconing coupled with lateral intrusion is theorized to produce composite chloride-concentration trends that vary widely over time in response to changing water demands, and evolve dynamically from hydraulic interactions among multiple neighboring production wells.

Some aspects of observation-well construction and sampling are of particular importance to monitoring saltwater movement in the Virginia Coastal Plain aquifer system. Observation wells should feature screened intervals generally of no more than 10 feet that isolate distinct parts of the aquifer, and be thoroughly developed for removal of drilling fluid and introduced water. Presample purging should fully displace stratified saltwater in the well casing upward to the pump. Stable flow should be maintained as field parameters are measured and sample containers are filled with filtered water isolated from the atmosphere and unaffected by surface temperature. Groundwater samples from both upconing and lateral-intrusion observation wells should initially be collected four times per year when wells are newly established, but can be more optimally timed with withdrawal once responses in chloride concentrations can be 
reliably predicted. Concentrations of major ions (1) determine the dominant chemical composition of groundwater at each well, (2) establish the relative position of the well within the saltwater-transition zone, and (3) provide data quality control by calculation of sample charge balance. For these reasons, samples initially collected for the first year from newly established observation wells should be analyzed for calcium, magnesium, sodium, and potassium cations and chloride, bicarbonate, carbonate, sulfate, fluoride, and bromide anions. Inflection-point titration for alkalinity should be completed in the field. Analysis of chloride and field parameters may be adequate on a long-term basis once the dominant chemical composition at each well is established. Specific conductance may also provide a surrogate for chloride concentration depending on regulatory policy.

The saltwater-movement monitoring strategy is limited and constrained. Relative monitoring needs among groundwater-production wells, and construction of observation wells, depend on the accuracy of previously mapped groundwater chloride iso-concentration surfaces. Production wells in similar proximity to saltwater can differ in aquifer hydraulic conductivity, rates of withdrawal, and screened-interval lengths. Only production wells making withdrawals reported to the Virginia Department of Environmental Quality have been accounted for; undocumented production wells can result in spurious changes in groundwater chloride concentration. Upconing observation wells should be as close as possible to corresponding production wells, so long as production wells are not damaged by borehole deviation. Projected locations of some lateral-intrusion observation wells may be precluded and require adjustment. Depths of upconing and lateral-intrusion observation wells may also require adjustment to be within the same aquifer as their corresponding production wells. Existing unused wells can be adapted as observation wells if differences from specified locations and construction are kept to a minimum and are accounted for. Where multiple production wells are in proximity, a modified monitoring approach may be needed to determine their net effect on changes in chloride concentration, and may require more than one lateral-intrusion observation well depending on the vertical positions of production-well screened intervals.

\section{Introduction}

Groundwater in the Coastal Plain Physiographic Province of eastern Virginia (fig. 1) is a heavily used resource. The rate of groundwater withdrawal is estimated to have been close to zero during the late $1800 \mathrm{~s}$, but increased continuously during the 20th century. By 2003, withdrawal rates from Coastal Plain aquifers in Virginia totaled approximately 117 million gallons per day (Mgal/d) (Heywood and Pope, 2009). As a result, groundwater levels have declined by as much as $150 \mathrm{feet}(\mathrm{ft})$ below sea level near large withdrawal centers, and sediment compaction has produced widespread land subsidence and exacerbated effects of sea-level rise (Pope and Burbey, 2004; Eggleston and Pope, 2013). Flow gradients have also been regionally reversed from a previously seaward direction to a landward direction, creating the potential for movement of saltwater through the aquifer system toward production wells. Withdrawals are likely to increase, which could result in further water-level decline, land subsidence, and potential saltwater contamination.

To manage the groundwater resource, the Virginia Department of Environmental Quality (VA DEQ) regulates groundwater withdrawals throughout the Virginia Coastal Plain. Withdrawals greater than 300,000 gallons per month must be approved under the VA DEQ Groundwater Withdrawal Permit Program (Code of Virginia, Title 62.1, Chapter 25). Groundwater users are required to submit information needed to evaluate the effects of their withdrawals on the aquifer system.

The VA DEQ relies on a sound scientific understanding of Virginia Coastal Plain geology and hydrology to make groundwater-management decisions. The U.S. Geological Survey (USGS) has been advancing knowledge of the geology and hydrology of the Virginia Coastal Plain since the beginning of the 20th century. A widely recognized description of the hydrogeology of the Virginia Coastal Plain resulted from the USGS Regional Aquifer-System Analysis (RASA) and related investigations completed during the 1980s (Meng and Harsh, 1988; Harsh and Laczniak, 1990). Subsequent investigations included discovery of the largest known meteor-impact crater in the United States buried beneath the lower Chesapeake Bay (Powars and Bruce, 1999; Powars, 2000). With knowledge of the impact crater, a complete redefinition of the aquifer system provides the most current (2015) and comprehensive understanding of groundwater conditions (McFarland and Bruce, 2006; Heywood and Pope, 2009; McFarland, 2010 and 2013; Eggleston and Pope, 2013). For more than three decades, results of USGS investigations have been extensively applied by the VA DEQ to evaluate the effects of groundwater withdrawals.

In addition to regulating groundwater withdrawals, the VA DEQ regulates the chemical quality of groundwater. Hence, effects of withdrawal-induced movement of saltwater on concentrations of chloride within parts of the Virginia Coastal Plain aquifer system are of concern. Drinking water must not exceed a chloride-concentration secondary maximum contaminant level (SMCL) of 250 milligrams per liter (mg/L) (U.S. Environmental Protection Agency, 1990). Some concentrations in groundwater, however, are as much as that of seawater (19,000 mg/L) and greater (McFarland, 2010). The potential for limitations on groundwater use, and (or) requirements to treat and substantially reduce chloride concentration, is therefore widespread. Saltwater contamination at some locations has been indicated by increases in chloride concentrations over time (McFarland, 2010). In addition, large amounts of brackish groundwater are being withdrawn at several primary production facilities, where costly desalination treatment is necessary before use. 
Fresh groundwater having a chloride concentration below the $250-\mathrm{mg} / \mathrm{L}$ SMCL is separated from saltwater along a saltwater-transition zone. In a simple coastal groundwater system, the saltwater-transition zone is positioned at land surface along the coastline and slopes downward and landward evenly beneath the surface (Barlow, 2003). By contrast, the saltwater-transition zone in the Virginia Coastal Plain has been mapped as far as 30 miles (mi) inland across the upper to middle parts of the aquifer system (McFarland, 2010), and is warped and steeply mounded in a roughly concentric fashion over and around sediments that fill the Chesapeake Bay impact crater (fig. 1, pl. 1). Landward of the impact crater, the saltwater-transition zone has been further delineated at a low angle across much of the deep part of the aquifer system as far as $70 \mathrm{mi}$ inland (McFarland, 2010).

In relation to the saltwater-transition zone, groundwater withdrawal in the Virginia Coastal Plain is also complexly distributed. Production wells that were regulated by the VA DEQ during 2013 widely span the area (fig. 1, pl. 1, attachment 1). Because of the position and unusual configuration of the saltwater-transition zone, the production wells are oriented to it at highly variable distances and directions. Well depths also span a broad range of vertical distances from the saltwater-transition zone. Saltwater moves toward production wells both horizontally by lateral intrusion and vertically by upconing. Wells to the west are laterally distant from saltwater, but upconing can still potentially contaminate wells of sufficient depth. Upconing is a more immediate but generally reversible cause of contamination, whereas lateral intrusion potentially results in a permanent reposition of the saltwatertransition zone. The two processes cannot be distinguished, however, from a single increase in chloride concentration.

The VA DEQ is currently (2015) developing a program to monitor the movement of saltwater and detect increases in chloride concentration before groundwater-production wells exceed the $250-\mathrm{mg} / \mathrm{L}$ SMCL. In a simple coastal groundwater system, lateral movement of saltwater takes place across a distinct front toward withdrawals of freshwater inland, and can be detected simply by periodically determining concentrations of chloride in groundwater across the intervening area. By contrast, no readily distinguishable front exists in the Virginia Coastal Plain across which saltwater movement toward production wells can be anticipated. Instead, proximity to saltwater, and the potential immediacy and permanence of contamination by vertical upconing and lateral intrusion, varies widely among individual production wells. The VA DEQ is therefore tailoring requirements among individual withdrawalpermit holders to monitor increases in groundwater chloride concentration that may exceed the $250-\mathrm{mg} / \mathrm{L}$ SMCL.

To address the complexity of movement of saltwater in the Virginia Coastal Plain, an investigation was undertaken during 2014 by the U.S. Geological Survey (USGS) in cooperation with the VA DEQ, to develop a conceptual framework and monitoring strategy for saltwater movement. Conditions, processes, and relations of saltwater to groundwater withdrawal were synthesized from previous studies.
Spatial relations between the saltwater-transition zone and regulated groundwater-production wells were also analyzed, and locations and other considerations for observation wells to monitor saltwater movement were determined.

\section{Purpose and Scope}

A conceptual framework and monitoring strategy is presented for movement of saltwater in the Virginia Coastal Plain aquifer system. The framework and strategy were developed to provide the VA DEQ with (1) a sound scientific understanding of the presence and movement of saltwater, and (2) operational guidance to implement a monitoring program. The conceptual framework consists of generalized descriptions synthesized from previous studies of conditions, processes, and relations of saltwater to groundwater withdrawal. The monitoring strategy is based on spatial relations between the saltwater-transition zone and 612 production wells that were regulated by the VA DEQ during 2013. Analysis identifies 81 production wells completed in the Yorktown-Eastover and Potomac aquifers from which chloride concentrations are most likely to increase above the $250-\mathrm{mg} / \mathrm{L} \mathrm{SMCL}$, and locations and depths of observation wells to distinguish vertical upconing from lateral intrusion among individual production wells. Aspects of observation-well construction and sampling are described that are of particular importance to monitoring saltwater movement in the Virginia Coastal Plain aquifer system. Limitations and constraints on monitoring are also discussed that must be recognized for effective strategy implementation.

\section{Description of the Study Area}

The Virginia Coastal Plain is about 13,000 square miles $\left(\mathrm{mi}^{2}\right)$ in size (fig. 1). Primary urban centers include the cities of Fredericksburg, Virginia, and Richmond, Va., along the western margin, and several cities and counties to the east and south. The remainder of the Virginia Coastal Plain is mostly rural and fairly evenly divided between cropland and forest. Land-surface altitude ranges from more than $300 \mathrm{ft}$ across some western uplands to $0 \mathrm{ft}$ along the Atlantic coast. Rolling terrain and deeply incised stream valleys are present to the northwest and gently rolling-to-level terrain, broad stream valleys, and extensive wetlands to the east and south. Primary rivers include the Potomac, Rappahannock, York, and James Rivers (fig. 1), and receive flow from dense and extensive networks of tributaries that extend across their entire drainage basins. These rivers collectively drain to the east and southeast into Chesapeake Bay and become estuarine upon entering the Virginia Coastal Plain. Distinct landmasses defined by the estuarine rivers include, from north to south, the Northern Neck, Middle Peninsula, York-James Peninsula, and Southeastern Virginia (fig. 1). Chesapeake Bay separates these parts of the Virginia Coastal Plain to the west from the Virginia Eastern Shore to the east. 


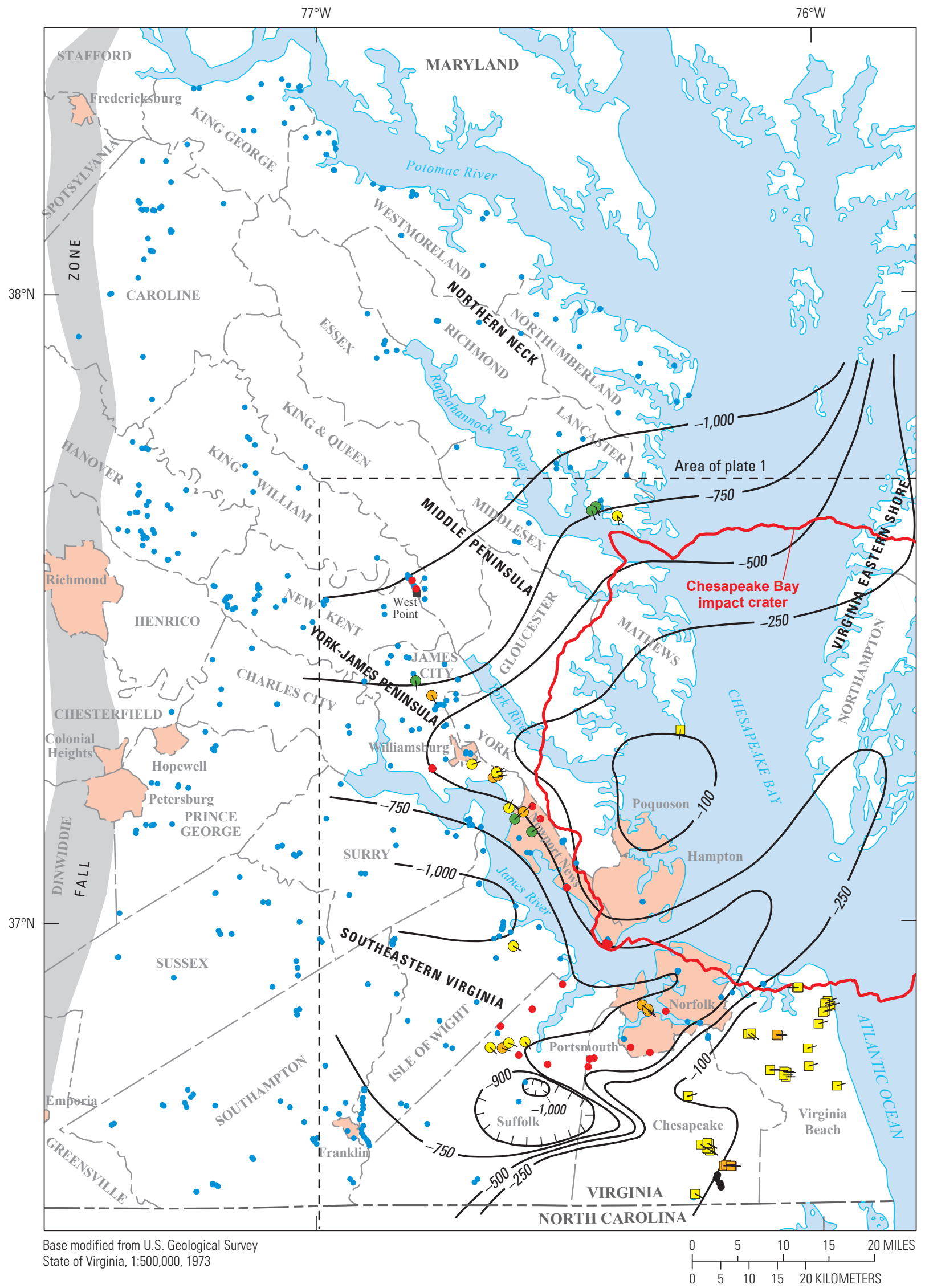




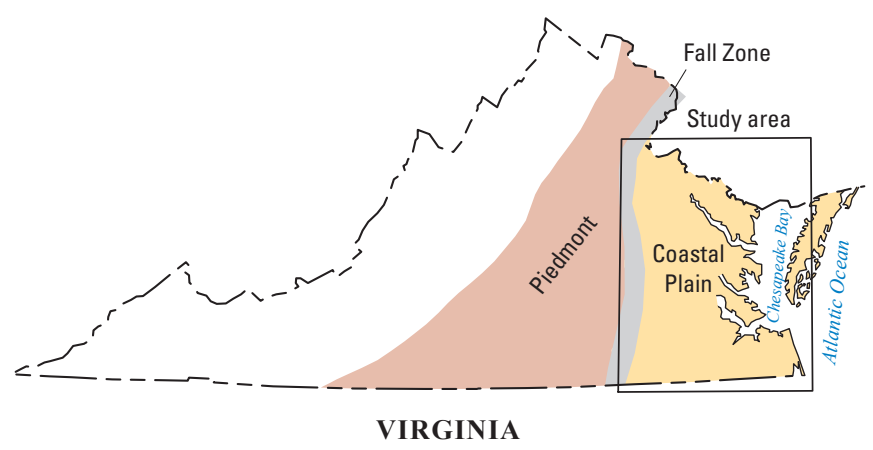

\section{EXPLANATION}

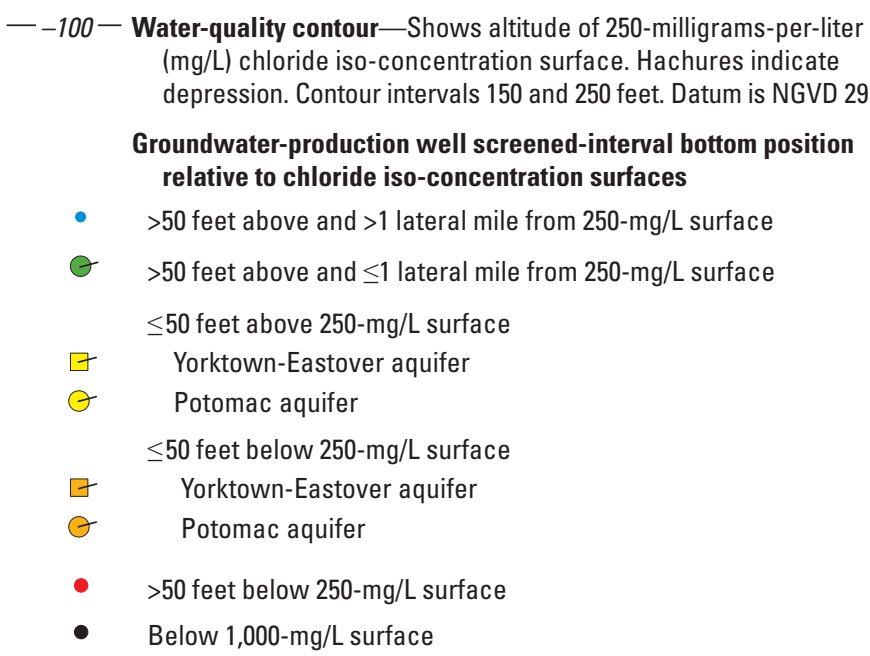

Figure 1 (pages 4 and 5). Locations of groundwaterproduction wells, projected locations of lateralintrusion observation wells, and the configuration of the 250-milligrams-per-liter chloride iso-concentration surface. Locations of groundwater-production wells regulated by the Virginia Department of Environmental Quality during 2013. Well symbols are color referenced to figures 7 and 8 , and attachment 1 . Symbol pointers indicate projected locations of lateral intrusion observation wells. Approximate altitude and configuration of the 250-milligrams-per-liter chloride iso-concentration surface modified from McFarland (2010). Location of Chesapeake Bay impact crater from Powars and Bruce (1999). Further detail shown on plate 1.

\section{Geologic Setting}

The Coastal Plain is underlain by a seaward-thickening wedge of regionally extensive, generally eastward-dipping strata of unconsolidated to partly consolidated sediments of Cretaceous, Paleogene, Neogene, and Quaternary age that unconformably overlie a basement of consolidated bedrock (fig. 2). The sediment wedge extends from Cape Cod, Massachusetts, southward to the Gulf of Mexico and offshore to the Continental Shelf. Sediment thickness in Virginia ranges from $0 \mathrm{ft}$ at its western margin to more than $6,000 \mathrm{ft}$ along the Atlantic coast. The sediments were deposited by seaward progradation of fluvial plains and deltas along the North American continental margin, followed by a series of transgressions and regressions by the Atlantic Ocean in response to changes in sea level. Fluvial strata primarily of Cretaceous age are overlain by marine strata of Paleogene and Neogene age, which are overlain in turn by terrace and floodplain deposits primarily of Quaternary age.

Coastal Plain sediments in Virginia were affected during the Paleogene Period by the impact of an asteroid or comet near the mouth of the present-day Chesapeake Bay (Powars and Bruce, 1999). The buried Chesapeake Bay impact crater is greater than $50 \mathrm{mi}$ in diameter and extends across a large part of the southeastern Virginia Coastal Plain (fig. 1). The crater formed within the preexisting sediments and contains unique impact-related materials as deep as basement bedrock. Subsequent deposition has buried crater-fill sediments about $1,000 \mathrm{ft}$ below the present-day land surface.

The Piedmont Physiographic Province (Piedmont) lies to the west of the Coastal Plain (figs. 1 and 2) and is underlain by igneous and metamorphic bedrock of late Proterozoic and early Paleozoic age, along with fault-bounded structural basins containing sedimentary and igneous bedrock of Triassic and Jurassic age. The transitional part of the Coastal Plain adjacent to the Piedmont is designated as the Fall Zone, a belt several miles wide across which streams have eroded through Coastal Plain sediments to expose Piedmont bedrock in their valley floors (Mixon and others, 1989). From the Fall Zone, the Piedmont bedrock slopes eastward beneath the sediment wedge to constitute the basement that underlies the Coastal Plain.

\section{Groundwater Conditions}

Sediments of the Virginia Coastal Plain are represented by a hydrogeologic framework (fig. 2) (McFarland and Bruce, 2006). Groundwater is present in pores between sediment grains. Permeable sediments that act as regionally extensive conduits for groundwater flow are designated as aquifers, and less permeable sediments that partly restrict flow are designated as confining units. Less distinct transitional intervals between aquifers and confining units are termed confining zones. Parts of some aquifers provide a widely used supply of water in Virginia. 


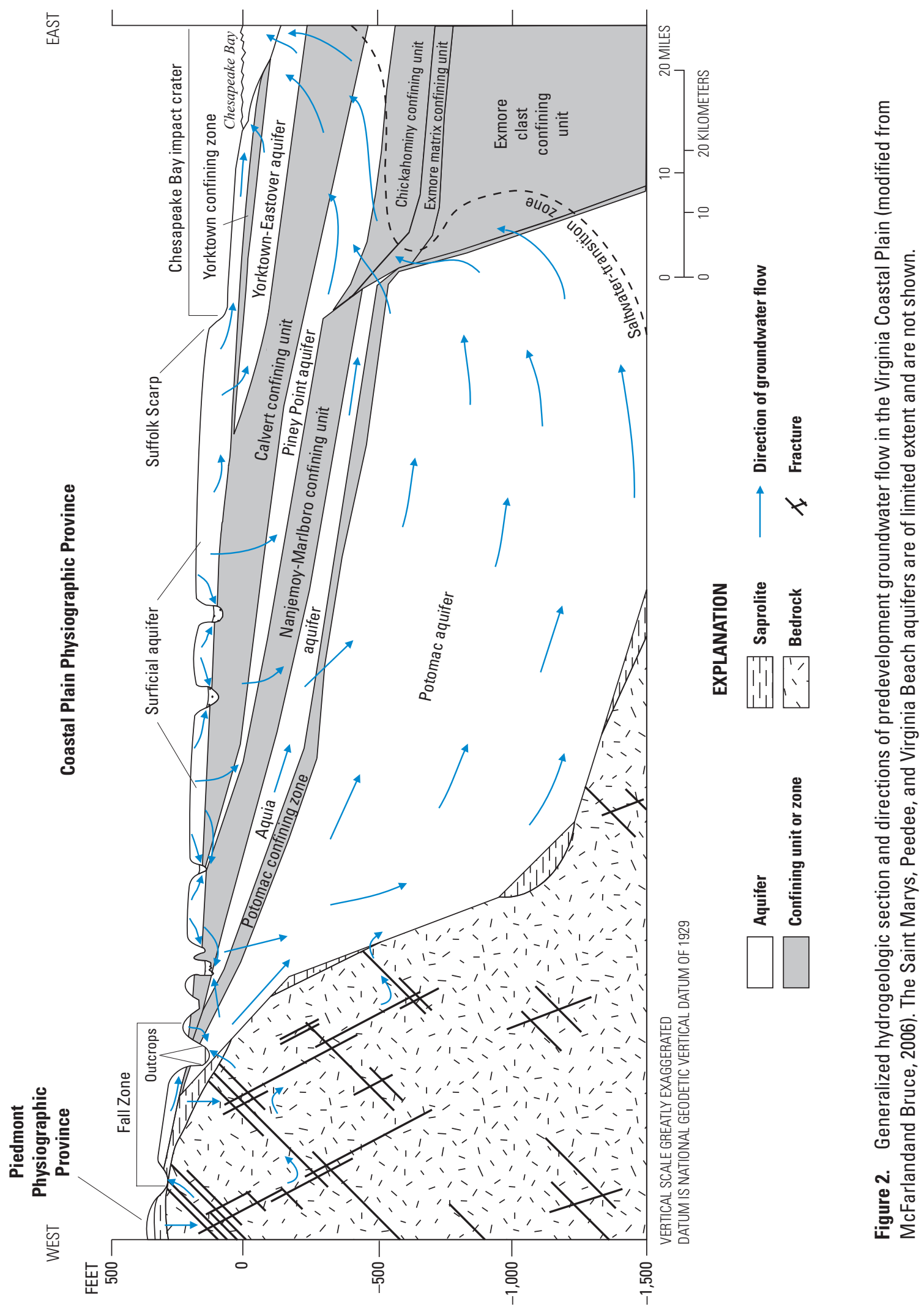


Twenty hydrogeologic units are currently (2015) recognized (McFarland and Bruce, 2006), including in downward order the following:

- Surficial aquifer,

- Yorktown confining zone,

- Yorktown-Eastover aquifer,

- Saint Marys confining unit,

- Saint Marys aquifer,

- Calvert confining unit,

- Piney Point aquifer,

- Chickahominy confining unit,

- Exmore matrix confining unit,

- Exmore clast confining unit,

- Nanjemoy-Marlboro confining unit,

- Aquia aquifer,

- Peedee confining zone,

- Peedee aquifer,

- Virginia Beach confining zone,

- Virginia Beach aquifer,

- upper Cenomanian confining unit,

- Potomac confining zone,

- Potomac aquifer, and

- bedrock.

The positions of hydrogeologic-unit margins do not coincide, and their areal distribution has a complex, overlapping "patchwork" configuration. Some units pinch out westward toward the Fall Zone, and major discontinuities are present along the margin of the Chesapeake Bay impact crater (fig. 2).

Groundwater in the Virginia Coastal Plain is recharged by precipitation that infiltrates the land surface and percolates to the water table. Unconfined groundwater flows short distances and discharges to nearby streams, but a small amount leaks downward to recharge the deeper confined aquifers (fig. 2) primarily along the Fall Zone and beneath surface-drainage divides between primary river valleys. Bedrock imposes a relatively impermeable underlying boundary. Flow through the confined aquifers is primarily lateral in the down-dip direction to the east toward large withdrawal centers and primary discharge areas along large rivers and the Atlantic coast. Contrasting density between freshwater and saltwater to the east causes the confined groundwater to discharge by upward leakage across intervening confining units. In addition, hydraulic boundaries along the Chesapeake Bay impact crater cause a lateral divergence of flow to either side of the impact crater (McFarland, 2010).

Groundwater withdrawal in the Virginia Coastal Plain increased continuously during the past century and has totaled nearly $100 \mathrm{Mgal} / \mathrm{d}$ for the past several decades (Heywood and Pope, 2009). The largest individual withdrawals supply industrial facilities at the cities of Franklin, Va., and West Point, Va. (fig. 1, pl. 1), where all but the deepest part of the aquifer system contains freshwater. Farther east and closer to saltwater, many additional large withdrawals supply public drinking water and diverse other uses, including several brackish groundwater development facilities that directly withdraw and treat water containing from several hundred to more than $1,000 \mathrm{mg} / \mathrm{L}$ of chloride. Most of these large withdrawals are regulated by the VA DEQ and are well documented. An estimated 200,000 small, unregulated, and mostly undocumented withdrawals also widely span the Virginia Coastal Plain and supply primarily individual domestic use (Pope and others, 2008).

Regional water-level cones of depression as deep as $150 \mathrm{ft}$ below sea level are centered on the two industrialwithdrawal locations about $60 \mathrm{mi}$ inland (fig. 3). As a result, the hydraulic gradient across the Virginia Coastal Plain has been regionally redirected landward and about doubled. Waterlevel declines from additional large withdrawals farther east have an additive effect on the aquifer system and contribute to the landward hydraulic gradient. Numerous but small individual domestic withdrawals probably result in only localized water-level declines. Region-wide rates of water-level decline vary between about 1 to 2 feet per year. Based on results of previous studies (Nelms and others, 2003; Heywood and Pope, 2009; McFarland, 2010 and 2013), probably several decades would be needed for water levels to stabilize in equilibrium with current (2015) withdrawals. In addition, much of the withdrawn water has been removed from aquifer storage rather than displaced across regionally appreciable distances. As a result, sediment compaction has produced widespread land subsidence and exacerbated effects of sea-level rise (Pope and Burbey, 2004; Eggleston and Pope, 2013).

\section{Methods of Investigation}

Withdrawal rates and allied information were compiled on 612 groundwater-production wells in the Virginia Coastal Plain and regulated by the VA DEQ during 2013 (attachment 1). To facilitate integration with the VA DEQ Groundwater Withdrawal Permit Program, production wells are identified by VA DEQ numbers. Maximum permitted withdrawal rates were obtained from the VA DEQ groundwater-withdrawal permitting database. Reported rates of actual withdrawals during 2013 were obtained from the groundwater-withdrawal permitting database and the VA DEQ Virginia Water Use Data System. Not all wells have both permitted and reported withdrawal rates. Withdrawal-rate data were cross-referenced to production-well location and screeninterval altitude data previously compiled for model simulations of groundwater flow. Aquifers in which the production wells are completed were determined from the hydrogeologic framework of McFarland and Bruce (2006) following the methodology described by McFarland (2010). Withdrawals are made by one or more of the production wells from all currently (2015) recognized aquifers of the Virginia Coastal 


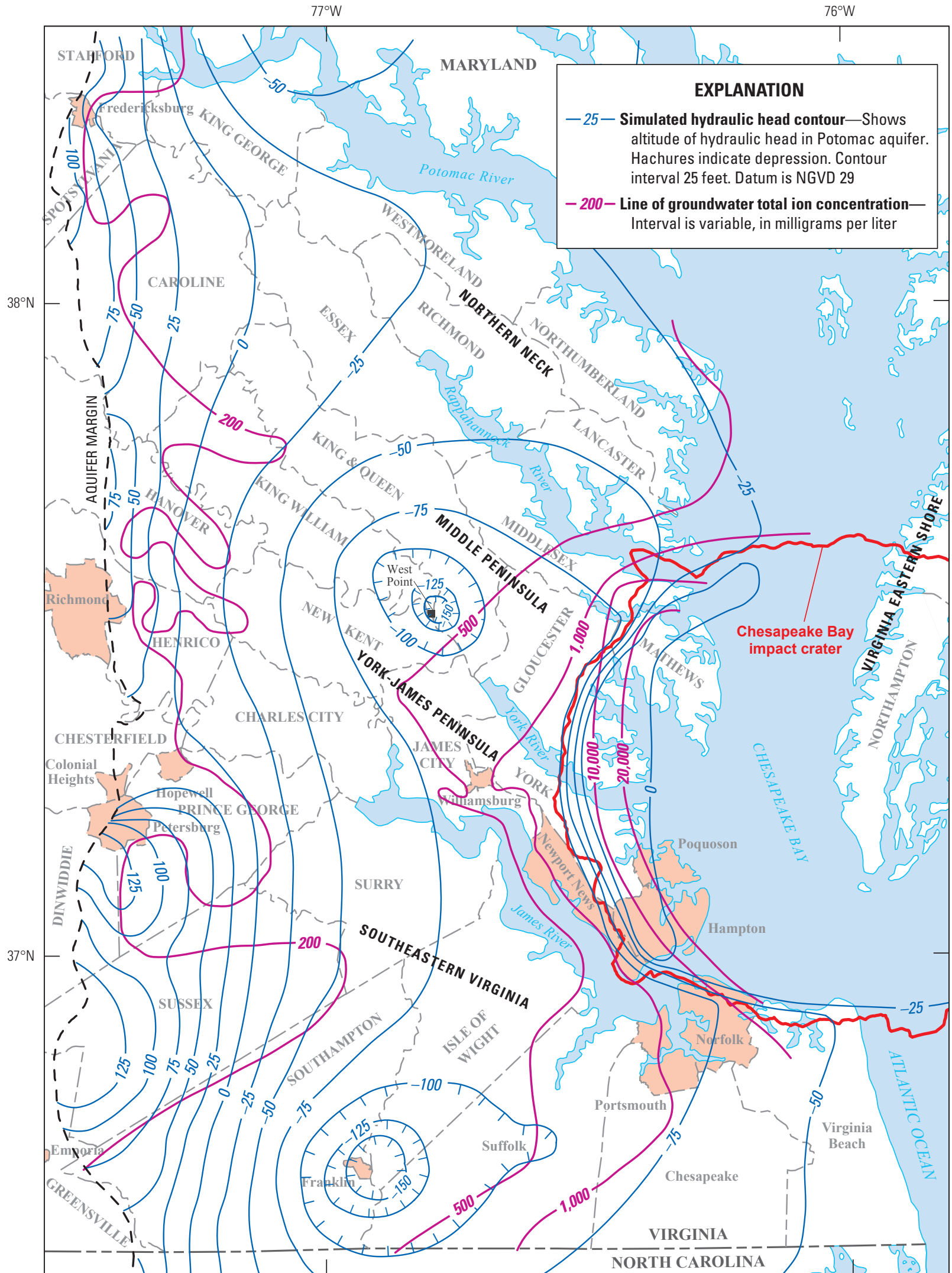

Base modified from U.S. Geological Survey State of Virginia, 1:500,000, 1973

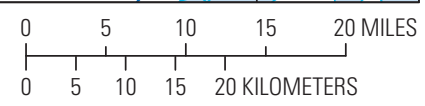

Figure 3. Simulated hydraulic head during 2003 and groundwater total ion concentration in the Potomac aquifer. Simulated hydraulic head contours modified from Heywood and Pope (2009). Total ion concentration contours modified from McFarland (2010). Location of Chesapeake Bay impact crater from Powars and Bruce (1999). 
Plain hydrogeologic framework (McFarland and Bruce, 2006), except the Saint Marys and Peedee aquifers, which are not developed for water supplies.

Proximity of all the production wells to saltwater was determined by a series of geographic information system (GIS) spatial analyses using groundwater $250-\mathrm{mg} / \mathrm{L}$ and $1,000-\mathrm{mg} / \mathrm{L}$ chloride iso-concentration surfaces previously mapped by McFarland (2010). Approximate configurations of the chloride surfaces are represented in the GIS by raster datasets and surface-altitude contour lines. The shapes of the two surfaces are about parallel but the 1,000-mg/L surface is positioned deeper. Production-well locations and related data were added to the GIS as georeferenced points. For these analyses, the bottom of the screened interval was considered to be the open part of each well in closest proximity to the chloride surfaces.

Operations were initially used in the GIS to identify the regionally estimated altitudes of the $250-\mathrm{mg} / \mathrm{L}$ and $1,000-\mathrm{mg} / \mathrm{L}$ chloride surfaces at each production-well location (attachment 1). The vertical position of the bottom of each well's screened interval was subsequently calculated relative to the chloride-surface altitudes. Positions below the chloride surfaces were assigned positive values, which designate the well as having penetrated the surfaces. Positions above the chloride surfaces were assigned negative values to designate no penetration. No data were generated for wells beyond the mapped extents of the chloride surfaces, for which cells are left blank in attachment 1. Production wells are categorized based on their vertical positions relative to the chloride surfaces, and are color referenced to figures 1,7 , and 8 , and plate 1 . Of the total 612 production wells, 81 wells in the Yorktown-Eastover and Potomac aquifers are positioned most closely to the $250-\mathrm{mg} / \mathrm{L}$ chloride iso-concentration surface. Within each category, production wells are listed in order of priority for monitoring based on vertical proximity to the chloride surfaces (attachment 1).

Lateral distances and directions of production wells to underlying chloride surfaces also were determined (attachment 1). Lateral distances and directions for wells above the $250-\mathrm{mg} / \mathrm{L}$ surface are relative to the $250-\mathrm{mg} / \mathrm{L}$ surface, and for wells below the $250-\mathrm{mg} / \mathrm{L}$ surface are relative to the $1,000-\mathrm{mg} / \mathrm{L}$ surface. The wells were classified based on the altitude of the bottom of each well's screened interval in closest vertical proximity to each chloride-surface altitude contour line. GIS operations were then used to calculate lateral distance and direction from the bottom of each well to the corresponding contour line. Direction is specified as degrees from east (fig. 4). With east being zero degrees, directions oriented counterclockwise from east are designated by positive values, and clockwise from east by negative values. GIS operations cannot calculate lateral distances and directions for some wells having screened-interval bottoms positioned above the maximum regional altitude of the $250-\mathrm{mg} / \mathrm{L}$ chloride surface. Instead, for wells within $50 \mathrm{ft}$ vertically of

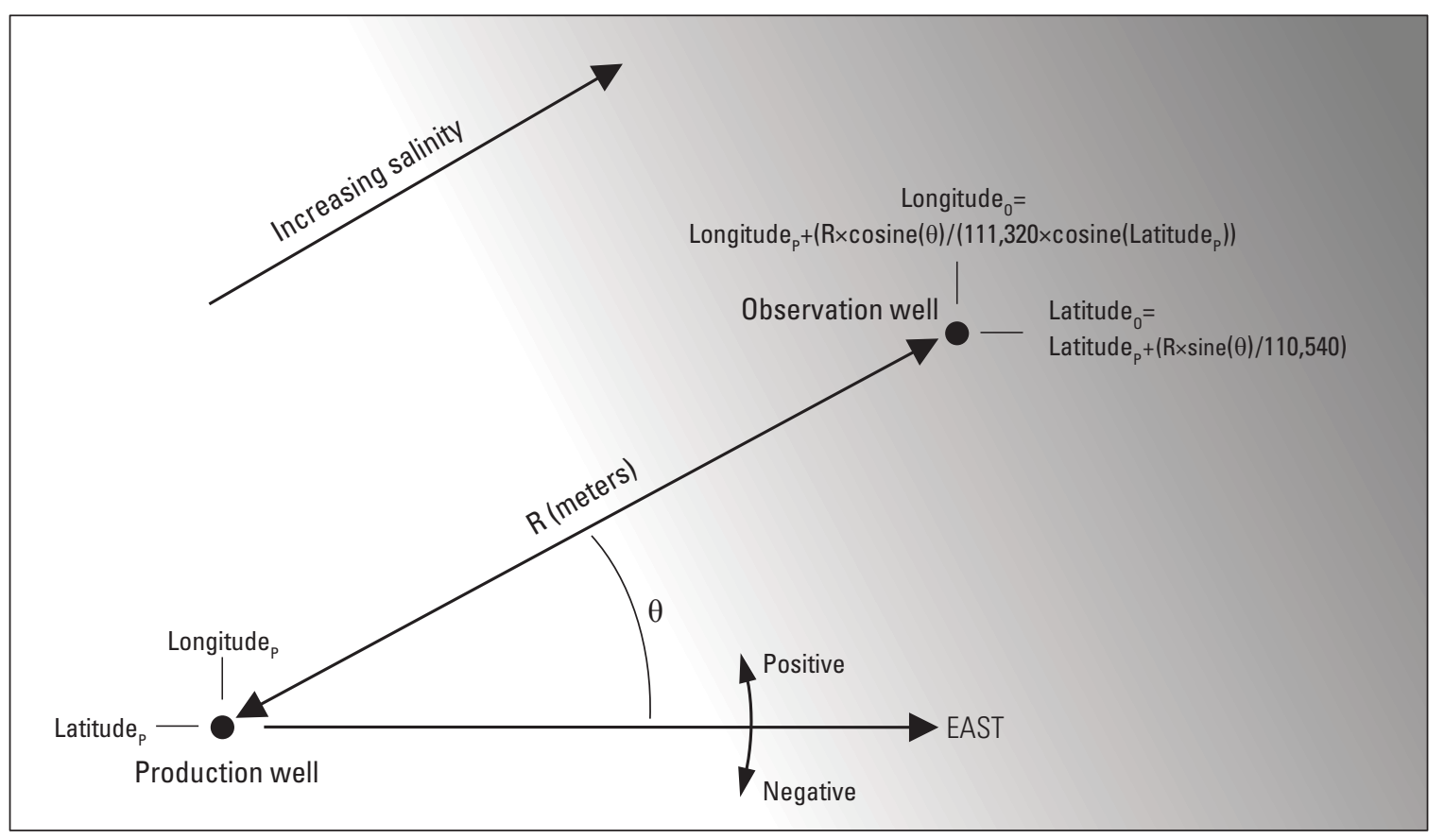

Figure 4. Projection of lateral intrusion observation-well location from groundwater-production well. Based on lateral directions to chloride surfaces, the observation well is positioned in the most proximal direction to saltwater (at the angle $\theta$ from east) at a distance $R$ of 1 mile $\left(1,609\right.$ meters) from the production well. Latitude ${ }_{0}$ and longitude ${ }_{0}$ of the observation well is calculated from latitude $e_{p}$ and longitude $e_{p}$ of the production well by formulas that apply trigonometric functions to the directions to saltwater. Formula coefficients account for variable distances spanned per unit of latitude and longitude that result from the curvature of the Earth's surface. 
the $250-\mathrm{mg} / \mathrm{L}$ chloride surface, lateral directions to the surface were manually estimated. Lateral distances and directions also were not calculated for wells below the $1,000-\mathrm{mg} / \mathrm{L}$ surface.

Lastly, locations for observation wells to monitor lateral saltwater intrusion were projected from the 81 production wells in the Yorktown-Eastover and Potomac aquifers that are positioned most closely to the $250-\mathrm{mg} / \mathrm{L}$ chloride iso-concentration surface (attachment 1). Observation-well locations are based on lateral directions to the $250-\mathrm{mg} / \mathrm{L}$ and $1,000-\mathrm{mg} / \mathrm{L}$ chloride surfaces. Latitudes and longitudes of the observation wells were calculated at a distance of $1 \mathrm{mi}$ from the latitudes and longitudes of the production wells by formulas that apply trigonometric functions to the directions to chloride surfaces (fig. 4). Formula coefficients account for variable distances spanned per unit of latitude and longitude that result from the curvature of the Earth's surface.

\section{Conceptual Framework of Saltwater in the Coastal Plain Aquifer System of Virginia}

Withdrawal-induced movement of saltwater in the Virginia Coastal Plain aquifer system is complex (see "Introduction" section). An adequate understanding of the presence and movement of saltwater is therefore fundamental to effective monitoring. Generalized descriptions of conditions, processes, and relations of saltwater to groundwater withdrawal are synthesized below from previous studies.

The most current (2015) and comprehensive hydrochemical description of the Virginia Coastal Plain aquifer system is presented by McFarland (2010). Water having chloride concentrations below the $250-\mathrm{mg} / \mathrm{L} \mathrm{SMCL}$ is commonly referred to as "fresh" and is present throughout much of the aquifer system. As exemplified by the Potomac aquifer (fig. 3), groundwater exhibits a marked eastward increase in total ion concentration along the western outer margin of the Chesapeake Bay impact crater. Here, chloride supersedes bicarbonate as the dominant anion in groundwater. Chloride concentrations between freshwater and that of seawater $(19,000 \mathrm{mg} / \mathrm{L})(\mathrm{Hem}, 1985)$ are referred to as "brackish," and are present in the eastern part of the aquifer system. Offshore, seawater occupies sediments beneath the Atlantic Ocean. Chloride concentrations above that of seawater constitute "brine" and have been observed in some sediments that fill the Chesapeake Bay impact crater (McFarland and Bruce, 2005; McFarland, 2010; Sanford and others, 2009, 2013).

\section{The Saltwater-Transition Zone}

In coastal groundwater systems, fresh groundwater is separated from underlying and denser saltwater by a downward and landward sloping boundary termed the saltwatertransition zone (Ghyben, 1888; Herzberg, 1901; Henry, 1960;
Barlow, 2003). The saltwater-transition zone encompasses a volume of sediments within which dispersive mixing takes place across a density gradient between freshwater and saltwater (fig. 5).

The saltwater-transition zone is a primary regional boundary on groundwater flow in the Virginia Coastal Plain (fig. 2). Fresh groundwater originating from recharge at the water table leaks downward into confined aquifers and-prior to large groundwater withdrawals - flowed downgradient to the east. Upon reaching dense saltwater along the coast, groundwater leaks back upward to discharge to the Atlantic Ocean, primary rivers, and Chesapeake Bay.

\section{Configuration}

The configuration of the saltwater-transition zone in the Virginia Coastal Plain is complex. A series of sub-parallel groundwater chloride iso-concentration surfaces-ranging from $50 \mathrm{mg} / \mathrm{L}$ to $19,000 \mathrm{mg} / \mathrm{L}$ - were mapped from chloride concentrations in 6,650 widely spaced samples of groundwater collected during 1906-2007 (McFarland, 2010). The chloride surfaces collectively represent the saltwater-transition zone, and indicate that groundwater chloride concentrations broadly increase eastward and downward.

As exemplified by the $250-\mathrm{mg} / \mathrm{L}$ chloride iso-concentration surface (fig. 1, pl. 1), the saltwater-transition zone in Virginia consists of two distinct components. Across the east-central part of the Virginia Coastal Plain, the saltwatertransition zone exhibits a warped and steeply mounded dome shape centered on the western to southwestern side of the Chesapeake Bay impact crater. A westward plunging spur ridge projects from the mound beneath the York-James Peninsula. Flank areas of the mound and ridge evenly slope northwestward beneath the Middle Peninsula and Northern Neck, and southwestward beneath Surry and Isle of Wight Counties.

Secondly, across the southeastern Virginia Coastal Plain, the saltwater-transition zone exhibits a nearly level plateau shape at shallow depth beneath the city of Virginia Beach, Va., and eastern city of Chesapeake, Va. (fig. 1, pl. 1). The landward margin of the plateau is irregularly shaped and slopes steeply downward to the west beneath the western city of Chesapeake, Va., and eastern city of Suffolk, Va. The plateau is also separated from the mound to the north by a southwestward plunging trough, trending from the southern tip of the Virginia Eastern Shore across the lowermost part of Chesapeake Bay and the cities of Norfolk, Va., and Portsmouth, Va.

\section{Formation}

Geologic and hydrochemical evidence indicates that much of the saltwater in the Virginia Coastal Plain aquifer system originated from seawater (McFarland and Bruce, 2005; McFarland, 2010) rather than earlier cited saltwater sources such as evaporate dissolution (Manheim and Horn, 1968; 

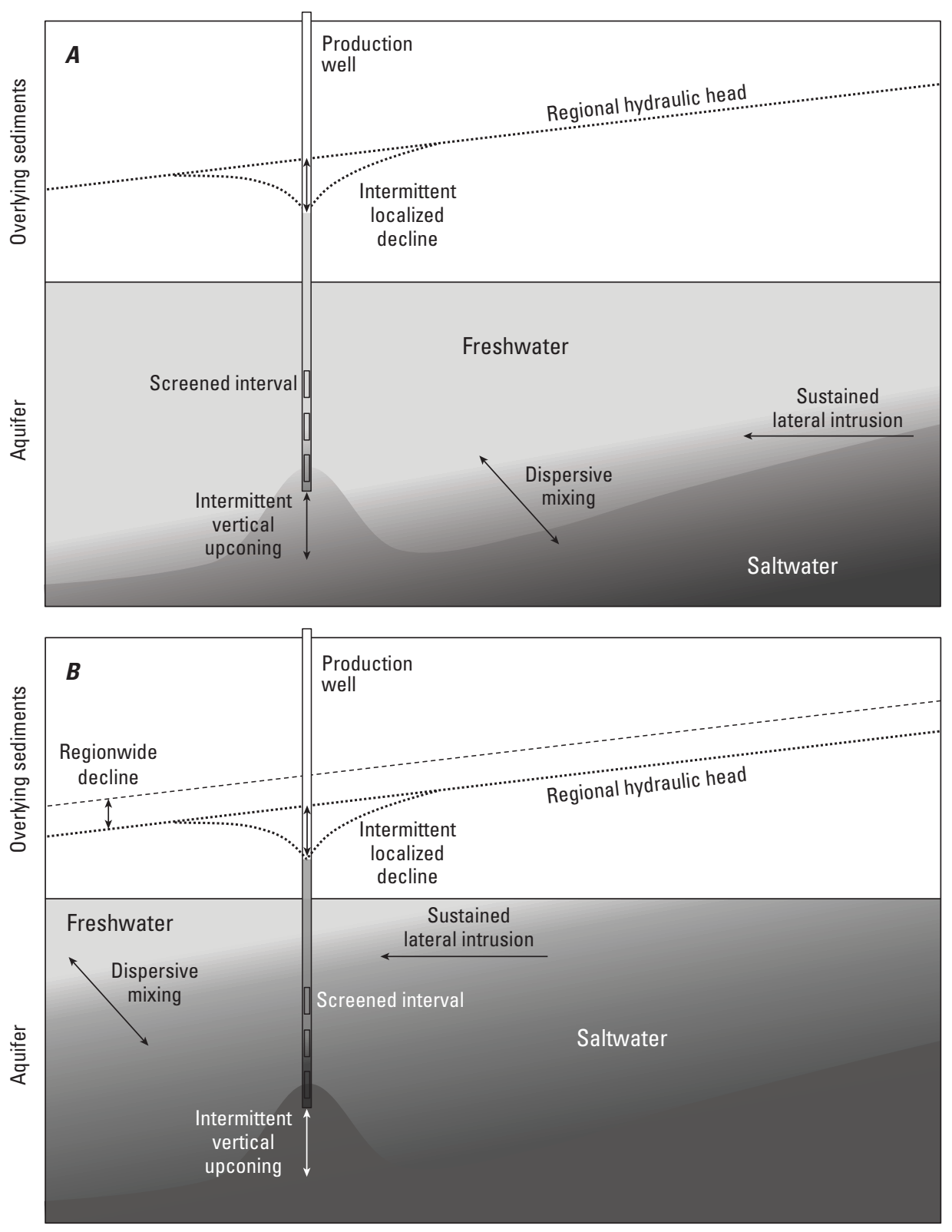

NOT TO SCALE

Figure 5. Movement of saltwater. A, Fresh groundwater is separated from underlying dense saltwater by the landward sloping saltwater-transition zone. Dispersive mixing takes place across a density gradient. Sustained lateral intrusion takes place with horizontal displacement across the regional hydraulic gradient. Intermittent upconing results directly beneath the pumping well from a density adjustment to localized water-level decline. $B$, Saltwater eventually shifts laterally landward during several decades. Upconing continues from farther into the saltwater-transition zone.

Meisler, 1989) or membrane filtration (Larson, 1981; Powars and Bruce, 1999). In addition, brine as much as twice the concentration of seawater has been found thousands of feet deep within the center of the Chesapeake Bay impact crater. The brine has been alternately attributed to impact-induced hydrothermal boiling (Sanford, 2003, 2005), exhumation of pre-impact sediments and (or) basement bedrock (Sanford and others, 2009), or partly land-locked Cretaceous-age basins (Sanford and others, 2013).
Seawater has been repeatedly emplaced within the aquifer sediments during cycles of submersion by the Atlantic Ocean during the past about 65 million years (McFarland, 2010). During emergent periods, eastward and downward flowing fresh groundwater flushed seawater from the sediments. Sea level had declined to the edge of the Continental Shelf during the Pleistocene glacial maximum from 18,000 to 21,000 years ago (Peltier, 1994; Bradley, 1999), when fresh groundwater likely flushed seawater from most of the sediments. Flushing 
was impeded, however, in low hydraulic conductivity sediments filling the Chesapeake Bay impact crater where seawater has been retained. Sea level has since risen to its current position and modern seawater is reentering submerged sediments. Flushing by fresh groundwater also continues, however, through sediments that are still emerged.

Before discovery of the Chesapeake Bay impact crater, the unusual configuration of the saltwater-transition zone in Virginia was recognized more than 100 years ago (Sanford, 1913). In addition, differential flushing of saltwater by fresh groundwater around a structural depression was theorized more than 70 years ago (Cederstrom, 1943). As exemplified by the $250-\mathrm{mg} / \mathrm{L}$ chloride iso-concentration surface (fig. 1, pl. 1), generally eastward flow of fresh groundwater is divided by the spur ridge that extends westward of the chloride mound beneath the York-James Peninsula. Seawater has probably been preferentially flushed around the Chesapeake Bay impact crater, either northeastward beneath the Middle Peninsula and Northern Neck or southeastward beneath Southeastern Virginia. Additionally, at several locations the broadly downward increasing chloride-concentration trend is locally reversed across distinct vertical intervals (McFarland, 2010, pls. 10,12, and 13). These inverted-concentration intervals have been correlated to infer continuous zones through which seawater has been flushed. Absence of any inverted-concentration intervals at the center of the impact crater (Sanford and others, 2009, 2013) indicates that flushing has not penetrated the center within which brine is restricted.

\section{Saltwater Movement}

Groundwater withdrawal has redirected the hydraulic gradient landward across the Virginia Coastal Plain (see "Groundwater Conditions" section). The resulting potential for region-wide saltwater movement toward withdrawal centers has been recognized for more than 40 years (Lichtler and Wait, 1974). The region-wide saltwater-transition zone, however, has remained in about the same position for more than 100 years (Sanford, 1913). Fresh groundwater has also been determined to reside in the sediments for tens of thousands of years (Nelms and others, 2003). Based on these considerations, withdrawn groundwater is apparently released primarily from aquifer storage rather than displaced across regionally appreciable distances. As a result, the position and configuration of the saltwater-transition zone still reflects pre-pumping coastward flushing of saltwater by fresh groundwater, and region-wide reconfiguration in response to groundwater withdrawal could possibly take centuries (McFarland, 2010).

Despite the apparent lack of region-wide movement of the saltwater-transition zone, changes in groundwater chloride concentration have been observed among individual wells (McFarland, 2010). Chloride concentrations have also been observed to increase in some newly pumped wells until their water levels stabilize (Cederstrom, 1943).

\section{Upconing and Lateral Intrusion}

Withdrawal-induced horizontal movement of saltwater is referred to herein as "lateral intrusion", and is distinct from upward vertical movement referred to as "upconing" (fig. 5). Lateral intrusion takes place with displacement of groundwater across a horizontal distance toward a pumping well. By contrast, upconing results from a density adjustment to a relatively small volume of water across a shorter vertical distance centered directly beneath the pumping well.

Upconing is generally regarded as the more common cause of changes in groundwater chloride concentration than lateral intrusion (Heath, 1987). Fresh groundwater in effect "floats" in dynamic equilibrium on more dense saltwater beneath (fig. 5). A 1-ft decline in freshwater head theoretically results in a localized rise in saltwater of $40 \mathrm{ft}$ (Ghyben, 1888; Herzberg, 1901) and recovery of the freshwater head results in a proportional deepening of saltwater. Dispersion, sediment heterogeneities, and flowing conditions, however, complicate this relation (Heath, 1987). Deepening of saltwater can lag behind recovery of freshwater head by weeks to months.

A general prevalence of fluctuating groundwater chloride concentrations in the Virginia Coastal Plain (see "Historical Changes in Groundwater Chloride Concentration" section) has been attributed to numerous instances of intermittent localized upconing that reverse with a decrease or cessation of withdrawal (McFarland, 2010). Many of the large groundwater withdrawals in the Virginia Coastal Plain are intermittent in response to cyclical water demands. Water-level declines and recoveries at production wells possibly result in localized chloride-concentration increases and decreases within weeks to months of changes in pumping. Where multiple neighboring production wells are operated at different times, complex hydraulic interactions can potentially cause concentration fluctuations to evolve dynamically (see "Chloride Concentration Trends" section).

Lateral intrusion probably occurs concomitantly with upconing in the Virginia Coastal Plain but more slowly. A production well's water-level decline may result in localized upconing, but is also superimposed on the regional hydraulic gradient (fig. 5A). A potential for lateral intrusion is created partly by the individual well, but also by the additive effect of all groundwater withdrawals throughout the aquifer system and contributing to the regional hydraulic gradient. Detailed long-term monitoring in the Coastal Plain of New Jersey during 1940-90 indicated that lateral intrusion across distances of about $1 \mathrm{mi}$ would take from 24 to 60 years (Lacombe and Carleton, 2002). In the Virginia Coastal Plain, based on groundwater ages (Nelms and others, 2003), corresponding lateral flow velocities (McFarland, 2013), and the current (2015) regional hydraulic gradient, lateral intrusion of 1 mi probably takes several decades or more. As saltwater slowly shifts laterally landward (fig. $5 B$ ), upconing to the production well may take place from farther within the saltwater-transition zone. As a result, localized groundwater 
chloride concentration fluctuations produced by upconing at many production wells are possibly superimposed on a slower, but more widespread and sustained concentration increase produced by lateral intrusion.

As long as the regional hydraulic gradient is maintained in a landward direction, the potential for lateral intrusion will persist. Lateral intrusion may be slow by human standards and have a less immediate effect than upconing. In contrast to the reversibility of upconing, however, lateral intrusion potentially results in a permanent reposition of the saltwatertransition zone.

\section{Historical Changes in Groundwater Chloride Concentration}

A historical record of 6,650 groundwater chemicalquality samples collected during 1906-2007 formed the basis for regional delineation of the saltwater-transition zone in Virginia (McFarland, 2010). The samples were collected at different times by various entities to achieve diverse objectives. As a result, most wells were not optimally located, constructed, or sampled for monitoring the movement of saltwater. Nonetheless, changes in groundwater chloride concentration were observed among a minority of individual wells, indicating at least localized saltwater movement in some form. Increases in concentration generally coincided with decreases in concentration, however, and neither increases nor decreases became larger or more frequent as groundwater withdrawal steadily increased during the past century. Neither was any consistent landward trend of increasing concentrations observed.

Only 10 wells have been identified among the historical data that were sampled an adequate number of times to determine site-specific trends in groundwater chloride concentration during periods of several years or more (McFarland, 2010). Only one shallow well had a substantial sustained increase in concentration (from less than $500 \mathrm{mg} / \mathrm{L}$ to about $3,500 \mathrm{mg} / \mathrm{L}$ during a 10 -year period), which was attributed to localized lateral intrusion of brackish river water from the nearby tidal James River. Elsewhere, another deeper well had a small gradual concentration increase (from about 2,100 mg/L to $2,700 \mathrm{mg} / \mathrm{L}$ during a 20 -year period), which was attributed to regional lateral intrusion of the saltwater-transition zone. The other 8 wells had either nearly constant concentrations varying by less than $100 \mathrm{mg} / \mathrm{L}$, or intermittent fluctuations as much as several hundred $\mathrm{mg} / \mathrm{L}$ that were attributed to localized upconing.

\section{Chloride-Concentration Trends}

On the basis of the processes and historical conditions documented by previous studies described above, possible general trends in groundwater chloride concentration near and within the saltwater-transition zone are theorized below. In proximity to active groundwater-production wells, vertical upconing coupled with lateral intrusion can result in a composite chloride-concentration trend (fig. 6). During periodic cycles of upconing, concentrations can increase from and decrease to a baseline concentration reflecting the regional position of the saltwater-transition zone. Based on historical groundwater chloride concentrations, some upconing cycles have lasted from several months to 2 years and spanned concentrations as much as several hundred $\mathrm{mg} / \mathrm{L}$ (McFarland, 2010). Lateral intrusion can also gradually increase the baseline concentration, but probably during a period of years to decades and by a small amount relative to concentration ranges spanned by upconing cycles.

Magnitudes, timing, and durations of upconing cycles are probably controlled by corresponding withdrawals and resulting water-level fluctuations, and may vary widely in response to changing water demands (fig. 6). Chloride concentrations during dormant periods without withdrawal may be unaffected by upconing and remain at the baseline level, varying only slightly as a result of lateral intrusion, differences in sampling conditions, or both. Conversely, prolonged withdrawal and water-level decline may maintain increased concentrations, and closely timed periods of withdrawal may interrupt full water-level recovery and prevent return of concentrations to baseline values that requires weeks to months.

Where a production well does not hydraulically interact directly with other production wells, fluctuations in groundwater chloride concentration may correspond directly with withdrawal and water-level decline at the single well. At many locations in the Virginia Coastal Plain, however, multiple production wells are in proximity, and some production facilities operate collocated wells. A complex local history of hydraulic interaction can potentially result from continually varying arrays of neighboring production wells taken in and out of service over time. Concentration fluctuations in some areas may be a dynamically evolving composite produced by the timing of pumping among multiple neighboring wells. Some neighboring production wells may also lack complete information or be wholly unknown. As a result, cause-andeffect relations between concentration fluctuations and withdrawals among multiple neighboring production wells can be difficult to discern.

In contrast to the above, groundwater chloride concentrations can be relatively constant under other conditions. Locations outside the immediate influence of any individual withdrawals may be unaffected by upconing, and chloride concentrations possibly vary only slightly around the baseline level reflecting the position of the saltwater-transition zone. Alternately, at locations where withdrawal is kept constant during multiple years, persistent upconing may be maintained without any intervening recovery or dormant periods. 


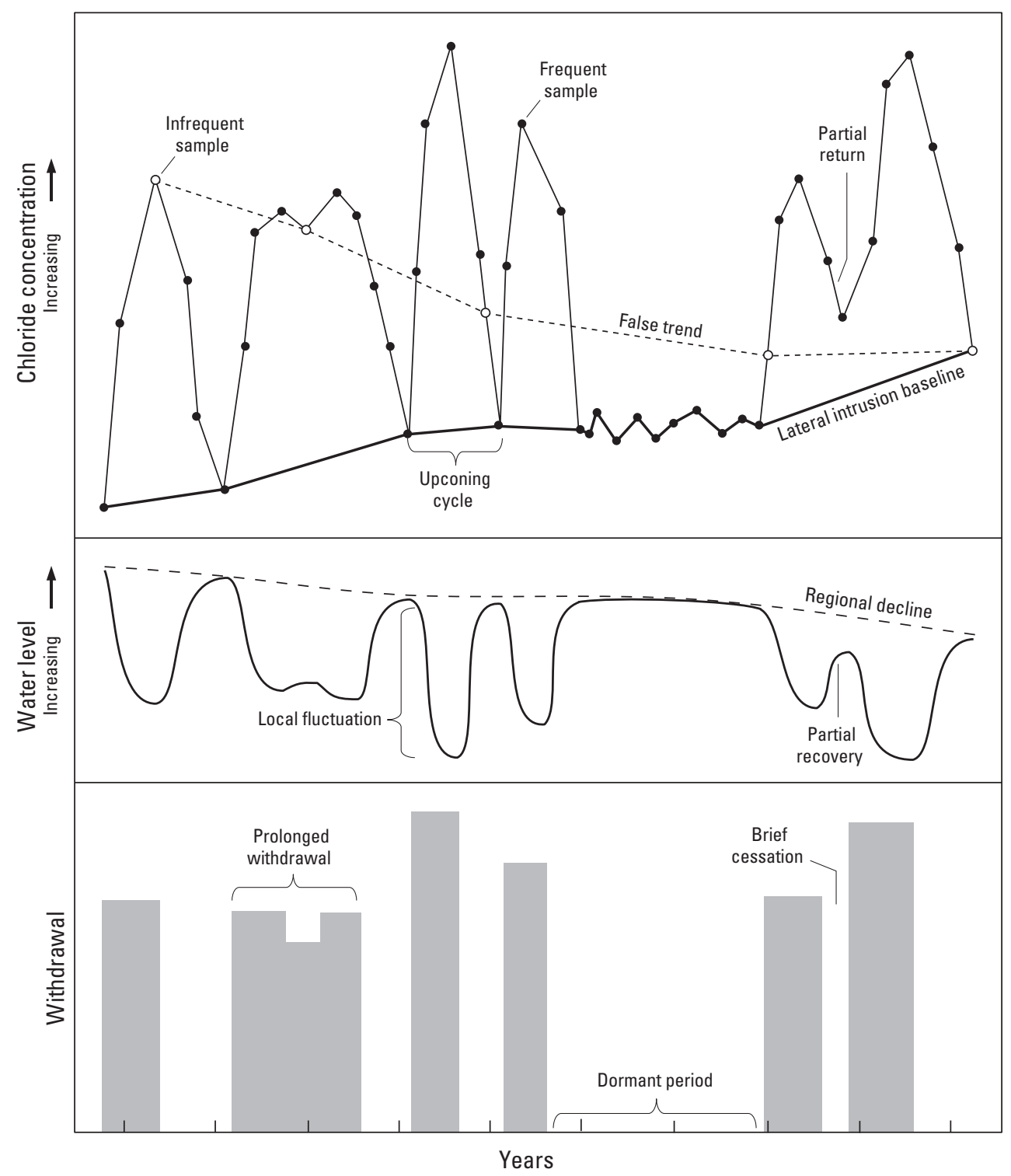

Figure 6. Generalized temporal relations among groundwater chloride concentrations, water levels, and withdrawals. Units are arbitrary. Vertical upconing is coupled with lateral intrusion to result in a composite chlorideconcentration trend. During upconing cycles, concentrations increase from and decrease to a baseline concentration reflecting the regional position of the saltwater-transition zone. Lateral intrusion gradually increases the baseline concentration. Upconing cycles are controlled by withdrawals and water-level fluctuations. During dormant periods, chloride concentrations can remain at the baseline level. Conversely, prolonged withdrawal and water-level decline can maintain increased concentrations. Closely timed withdrawals can interrupt water-level recovery and return of concentrations to baseline values. Frequent samples (black dots) distinguish upconing from lateral intrusion, whereas infrequent samples (white dots) can produce a false chlorideconcentration trend.

\section{Monitoring Strategy for Movement of Saltwater in the Coastal Plain Aquifer System of Virginia}

A strategy to monitor the movement of saltwater in the Virginia Coastal Plain aquifer system was developed from an understanding of conditions, processes, and relations of saltwater to groundwater withdrawal (see "Conceptual Framework" section). On the basis of spatial relations between the saltwater-transition zone and 612 regulated groundwaterproduction wells, 81 production wells were identified from which chloride concentrations are most likely to increase above the $250-\mathrm{mg} / \mathrm{L} \mathrm{SMCL}$. Potential locations of observation wells to monitor saltwater movement were determined to distinguish vertical upconing from lateral intrusion among individual production wells. For effective strategy implementation, observation-well construction and development, and groundwater-sample collection technique, frequency, and analysis must be tailored to monitoring the movement of saltwater in the Virginia Coastal Plain aquifer system. Limitations and constraints on monitoring saltwater movement must also be recognized.

\section{Proximity of Groundwater-Production Wells to Saltwater}

To provide a basis for monitoring saltwater movement, spatial relations between the saltwater-transition zone and regulated groundwater-production wells were determined. GIS analyses were completed on 612 production wells for which the VA DEQ provided actual and maximum permitted withdrawal rates for 2013, and well location and screeninterval altitude data (see "Methods of Investigation" section). Withdrawals are made by one or more of the production wells from all currently (2015) recognized aquifers of the Virginia 
Coastal Plain hydrogeologic framework (McFarland and Bruce, 2006) except the Saint Marys and Peedee aquifers, which are not developed for water supplies. The vertical position of the bottom of each well's screened interval, and its lateral distance and direction, were determined relative to previously mapped groundwater $250-\mathrm{mg} / \mathrm{L}$ and $1,000-\mathrm{mg} / \mathrm{L}$ chloride iso-concentration surfaces (McFarland, 2010). Screened-interval bottom vertical positions, and lateral distances and directions to the chloride surfaces are included with compiled production-well withdrawal rates and allied information (attachment 1).

In order to identify production wells from which chloride concentrations are most likely to increase above the $250-\mathrm{mg} / \mathrm{L}$ SMCL, the production wells are categorized relative to the 250-mg/L and 1,000-mg/L chloride iso-concentration surfaces. Categories are based on vertical and lateral distances of the bottoms of well screened intervals to the chloride surfaces (figs. 1 and 7,pl. 1). Also as a means to prioritize relative needs for monitoring, the wells are listed within each category in order of vertical proximity to the $250-\mathrm{mg} / \mathrm{L}$ chloride surface (attachment 1).

Screened-interval bottoms of 495 of the 612 production wells (colored blue, figs. 1 and 7, pl. 1) are either more than $50 \mathrm{ft}$ above and $1 \mathrm{mi}$ laterally from the $250-\mathrm{mg} / \mathrm{L}$ chloride surface, or are beyond the mapped extent of the surface. These wells are screened in several different aquifers and located across most of the Virginia Coastal Plain. Within the accuracy of the chloride surfaces (see "Limitations and Constraints" section), they are considered to be farthest from saltwater and least likely to increase above the $250-\mathrm{mg} / \mathrm{L}$ chloride SMCL.

Other production wells that are closer to or below the 250-mg/L chloride iso-concentration surface are more likely to increase above the 250-mg/L SMCL. Among these, screenedinterval bottoms of 5 wells are more than $50 \mathrm{ft}$ above but

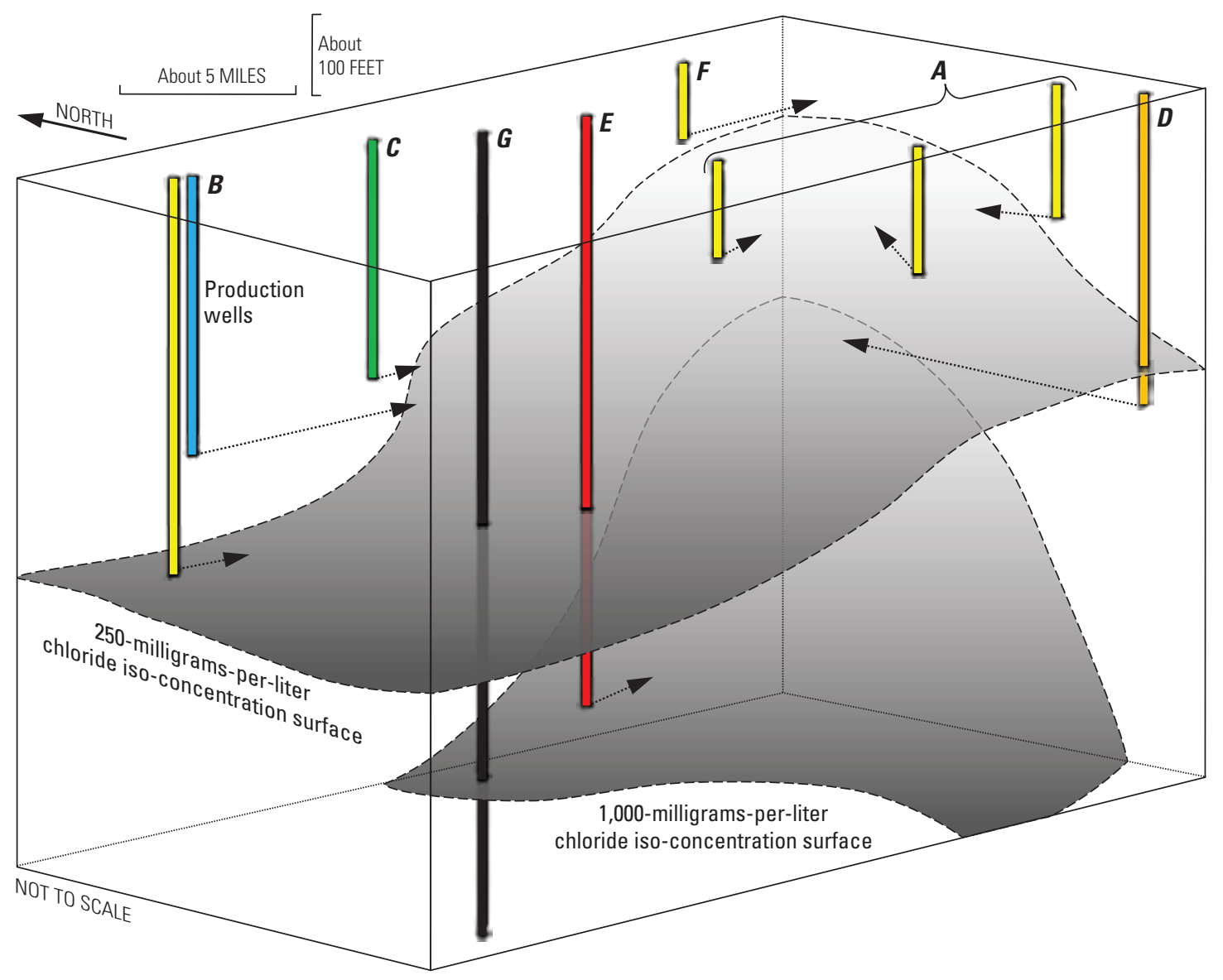

Figure 7. Generalized spatial relations of groundwater-production wells to chloride iso-concentration surfaces. Wells are color referenced to figures 1 and 8, plate 1, and Attachment 1. A, Lateral directions to a chloride surface vary among well locations. $B$, Lateral distances to a chloride surface at a single location varies with well depth. $C$, Where a chloride surface is steeply inclined, a well can be more than 50 feet above but less than 1 mile laterally from the surface. $D$ and $E$, The lateral direction to saltwater is relative to the 1,000-milligrams-per-liter chloride surface for wells below the 250-milligrams-per-liter chloride surface. $F$, Lateral directions to saltwater were manually estimated for wells that are shallower than the highest altitude of the chloride surface. G, Lateral distances and directions to saltwater were not determined for wells below the 1,000-milligrams-per-liter surface. 
less than $1 \mathrm{mi}$ laterally from the $250-\mathrm{mg} / \mathrm{L}$ chloride surface (colored green, figs. 1 and 7, pl. 1). These wells are all in the Potomac aquifer and arrayed along the flanks of the mounded part of the saltwater-transition zone where the $250-\mathrm{mg} / \mathrm{L}$ surface is steep. Screened-interval bottoms of 54 additional wells (colored yellow) are within $50 \mathrm{ft}$ above the $250-\mathrm{mg} / \mathrm{L}$ surface. These wells include 45 in the Yorktown-Eastover aquifer (square symbols), which are mostly positioned across the plateau part of the saltwater-transition zone far to the southeast, along with one well over the salinity mound at the southern tip of Mathews County, Va. The other 9 wells are in the Potomac aquifer (circle symbols), and are positioned either at the westward margin of the plateau or along the flanks of the mound. Chloride concentrations in wells within $50 \mathrm{ft}$ above or $1 \mathrm{mi}$ laterally from the $250-\mathrm{mg} / \mathrm{L}$ surface may be close to the $250-\mathrm{mg} / \mathrm{L}$ SMCL and likely to increase above it depending on (1) the accuracy of the chloride surfaces, (2) aquifer hydraulic conductivities, (3) well withdrawal rates, and (4) the lengths and vertical positions of well screened intervals intercepting overlying fresh groundwater (see "Limitations and Constraints" section).

Screened-interval bottoms of 22 production wells are within $50 \mathrm{ft}$ below the $250-\mathrm{mg} / \mathrm{L}$ chloride iso-concentration surface (colored orange, figs. 1 and 7, pl. 1). These wells include 12 in the Yorktown-Eastover aquifer (square symbols) positioned across the salinity plateau, and 10 in the Potomac aquifer (circle symbols) positioned either at the westward margin of the plateau or along the flanks of the salinity mound. Chloride concentrations in these wells may be close to the $250-\mathrm{mg} / \mathrm{L}-\mathrm{SMCL}$ or have already marginally exceeded it depending on (1) the accuracy of the chloride surfaces, (2) aquifer hydraulic conductivities, (3) well withdrawal rates, and (4) the lengths and vertical positions of screened intervals intercepting overlying fresh groundwater (see "Limitations and Constraints" section).

Screened-interval bottoms of another 24 production wells are more than $50 \mathrm{ft}$ below the $250-\mathrm{mg} / \mathrm{L}$ chloride surface but are above the 1,000-mg/L surface (colored red, figs. 1 and 7, pl. 1). These wells are all in the Potomac aquifer and positioned either at the westward margin of the salinity plateau or along the flanks of the salinity mound. Chloride concentrations in these wells probably have already exceeded the $250-\mathrm{mg} / \mathrm{L}$

SMCL, depending on (1) the accuracy of the chloride surfaces, (2) aquifer hydraulic conductivities, (3) well withdrawal rates, and (4) the lengths and vertical positions of screened intervals intercepting overlying fresh groundwater (see "Limitations and Constraints" section).

Lastly, screened-interval bottoms of 12 production wells are below the 1,000-mg/L surface at widely scattered locations in James City County, Va. and the cities of Newport News, Va., Portsmouth, Va., and Chesapeake, Va. (colored black, figs. 1 and 7, pl. 1). These wells are all in the Potomac aquifer and constitute parts of primary groundwater-production facilities that withdraw and treat brackish groundwater from far within the saltwater-transition zone.
Several spatial relations are apparent between production wells and the chloride surfaces. Wells arrayed along the flanks of the salinity mound can have widely varying lateral directions to saltwater (fig. $7 A$ ). Lateral and vertical proximity to chloride surfaces at any location can differ substantially depending on well depth (fig. $7 B$ ). Where chloride surfaces are steep, lateral distance can be relatively short compared to vertical distance (fig. $7 C$ ). The lateral direction for wells positioned below the $250-\mathrm{mg} / \mathrm{L}$ chloride surface is relative to the underlying $1,000-\mathrm{mg} / \mathrm{L}$ chloride surface (figs. $7 D$ and $7 E$ ). Where the $250-\mathrm{mg} / \mathrm{L}$ chloride surface is at a low angle, lateral directions were manually estimated for wells with screen-interval bottoms positioned above the highest regional altitude of the chloride surface (fig. $7 F$ ) (see "Methods of Investigation" section).

\section{Observation Wells}

Potential locations of observation wells to monitor saltwater movement were determined. Based on spatial analyses of 612 regulated groundwater-production wells (see "Proximity of Groundwater-Production Wells to Saltwater" section), 81 production wells in the Yorktown-Eastover and Potomac aquifers were identified as having screened-interval bottoms positioned most closely to the $250-\mathrm{mg} / \mathrm{L}$ chloride isoconcentration surface (table 1, in back of report). Chloride concentrations in these production wells are the most likely to increase above the $250-\mathrm{mg} / \mathrm{L}$ SMCL depending on (1) the accuracy of the chloride surfaces, (2) aquifer hydraulic conductivities, (3) well withdrawal rates, and (4) the lengths and vertical positions of screened intervals intercepting overlying fresh groundwater (see "Limitations and Constraints" section). As a means to prioritize relative needs for monitoring, the production wells are listed in order of vertical proximity to the $250-\mathrm{mg} / \mathrm{L}$ chloride surface. Conditions at and near some production wells may constrain the construction of observation wells (see "Limitations and Constraints" section).

Of the 81 production wells, 5 have screened-interval bottoms positioned more than $50 \mathrm{ft}$ above but less than $1 \mathrm{mi}$ laterally from the $250-\mathrm{mg} / \mathrm{L}$ chloride surface (colored green, figs. 1 and 7, pl. 1). Screened-interval bottoms of an additional 54 wells are within $50 \mathrm{ft}$ above the $250-\mathrm{mg} / \mathrm{L}$ chloride surface (colored yellow), and 22 wells are within $50 \mathrm{ft}$ below the $250-\mathrm{mg} / \mathrm{L}$ chloride surface (colored orange). Of the 81 production wells, 57 are completed in the YorktownEastover aquifer (square symbols) and 24 in the Potomac aquifer (circle symbols). Locations of the production wells span the mounded part of the saltwater-transition zone across the east-central Virginia Coastal Plain, and the plateau part of the saltwater-transition zone far to the southeast.

Potential locations for observation wells to monitor saltwater movement were not determined for 495 production wells either beyond the mapped extent of the $250-\mathrm{mg} / \mathrm{L}$ chloride surface or having screened-interval bottoms more than $50 \mathrm{ft}$ above and $1 \mathrm{mi}$ laterally from the surface (colored 
blue, figs. 1 and 7, pl. 1). Chloride concentrations in these wells are least likely to increase above the 250-mg/L SMCL. Neither were observation-well locations determined for 24 production wells having screened-interval bottoms more than $50 \mathrm{ft}$ below the $250-\mathrm{mg} / \mathrm{L}$ chloride surface (colored red) or 12 production wells positioned below the $1,000-\mathrm{mg} / \mathrm{L}$ chloride surface (colored black) that probably already exceed the 250-mg/L SMCL.

\section{Locations}

Potential locations were determined for observation wells to monitor both vertical upconing and lateral intrusion of saltwater among individual groundwater-production wells (see "Saltwater Movement" section). To monitor upconing, an observation well is to be collocated with each of the 81 production wells and completed at about the altitude of the 250-mg/L chloride iso-concentration surface (fig. 8). Altitudes of chloride surfaces at the production wells are included with compiled production-well withdrawal rates and allied information (table 1, attachment 1). Care should be used during drilling so that boreholes do not vertically deviate to intercept and damage nearby production wells (see "Construction of Observation Wells" section).

To monitor lateral intrusion, locations for observation wells were projected from production wells based on lateral directions to underlying chloride surfaces (see "Methods of Investigation" section). Latitudes and longitudes were calculated at a distance of $1 \mathrm{mi}$ from the production wells, and are included with the compiled production-well withdrawal rates and allied information (table 1, attachment 1).

The locations of lateral-intrusion observation wells are projected in the nearest directions to saltwater from the production wells, within the accuracy of the chloride isoconcentration surfaces (see "Limitations and Constraints" section). Because a localized water-level decline created by each production well is superimposed on the regional hydraulic gradient (fig. 5), lateral intrusion to the production well is most likely along the projected direction.

The specified distance of $1 \mathrm{mi}$ from production wells to lateral-intrusion observation wells is based on (1) an adequate separation from the production wells to avoid fluctuations in groundwater chloride concentrations resulting from upconing and (2) an appropriate time horizon for resource management. Documented aquifer tests in the Virginia Coastal Plain that included observation wells more than a few hundred feet from pumping wells showed no water-level response (McFarland, 2013). The effect of upconing at production wells is therefore presumed to be less than $1 \mathrm{mi}$. The distance traversed by lateral intrusion during a period of several decades also is about $1 \mathrm{mi}$, based on groundwater ages (Nelms and others, 2003), corresponding lateral flow velocities (McFarland, 2013), the current (2015) regional hydraulic gradient in the Virginia

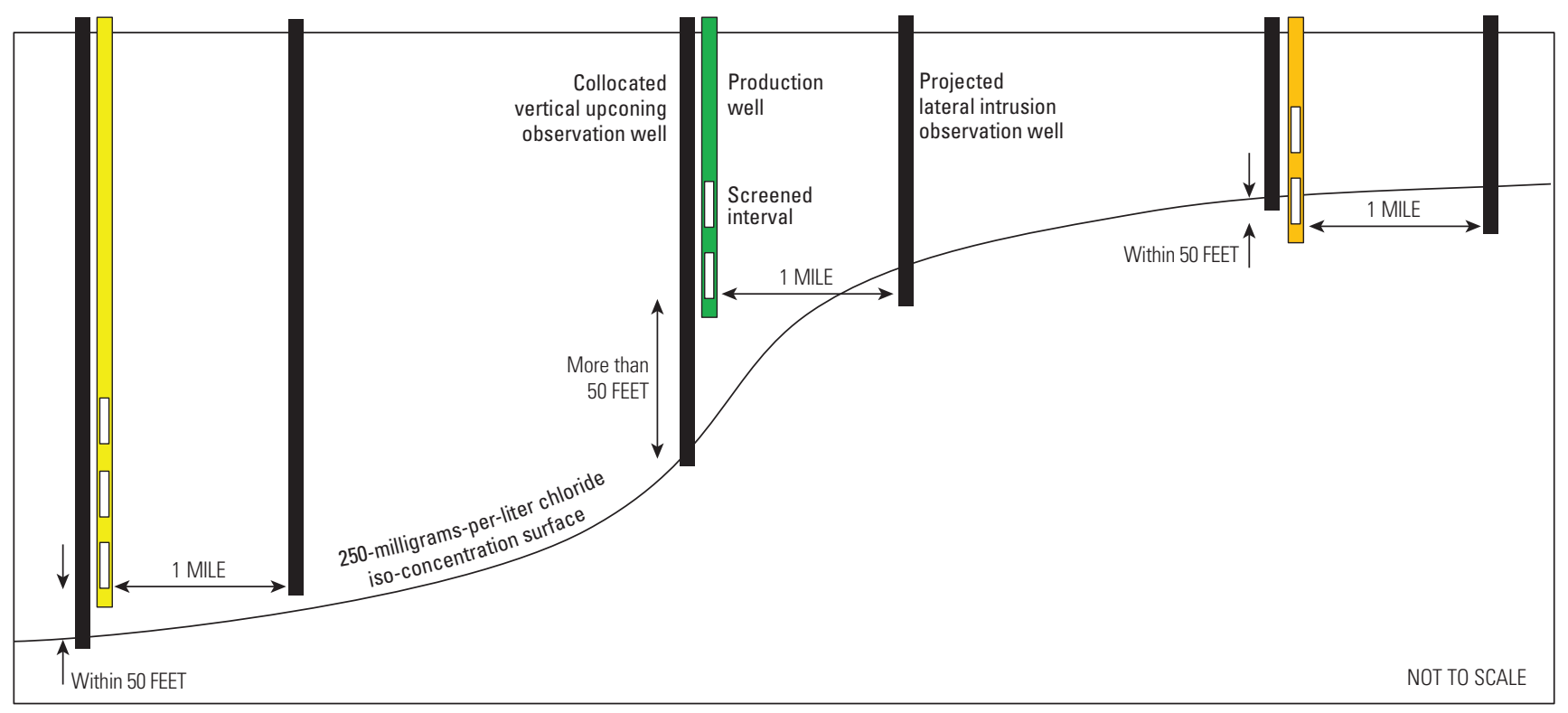

Figure 8. Generalized spatial relations among groundwater-production wells, observation wells, and the 250-milligrams-per-liter chloride iso-concentration surface. Production wells are color referenced to figures 1 and 7, plate 1, and attachment 1. Locations are specified for observation wells to monitor both vertical upconing and lateral intrusion among 81 individual groundwaterproduction wells. To monitor upconing, an observation well is collocated with each production well and completed at the altitude of the 250-milligrams-per-liter chloride iso-concentration surface. To monitor lateral intrusion, a location for an observation well is projected at a distance of 1 mile from each production well, based on lateral directions to underlying chloride surfaces. Chloride iso-concentration surface altitudes, and lateral intrusion production-well latitudes and longitudes, are included with productionwell withdrawal rates and allied information (table 1 and attachment 1). 
Coastal Plain, and similar rates of lateral intrusion estimated in the New Jersey Coastal Plain (Lacombe and Carleton, 2002).

For production wells having screened-interval bottoms positioned above the $250-\mathrm{mg} / \mathrm{L}$ chloride surface (colored green and yellow, figs. $7 A-C$ and $F$ ), lateral-intrusion observation well locations are projected in the direction to the $250-\mathrm{mg} / \mathrm{L}$ surface. Conversely, for production wells having screenedinterval bottoms positioned below the $250-\mathrm{mg} / \mathrm{L}$ chloride surface (colored orange, fig. $7 D$ ), locations are projected in the directions to the underlying 1,000-mg/L chloride surface. Because chloride surfaces are sub-parallel, however, directions to the two chloride surfaces from an individual production well are generally similar.

\section{Construction and Development}

A large body of literature documents numerous considerations to be taken into account in the construction and use of observation wells. Considerable knowledge and experience also is required to successfully implement complex procedures involved in well drilling and collection of groundwater chemical-quality samples. The reader is directed to Claassen (1982), Lapham and others (1997), and Wilde (1999), among the many sources available for a complete discussion. Only selected aspects that are of particular importance to monitoring saltwater movement in the Virginia Coastal Plain aquifer system are summarized below.

During drilling of any observation wells in proximity to preexisting wells, care should be used so that boreholes do not vertically deviate to the extent that they would intercept and damage the preexisting wells. Upon completion, observationwell screened intervals should effectively isolate the parts of the aquifer either (1) for upconing observation wells, at the altitude where chloride concentrations approximating $250 \mathrm{mg} / \mathrm{L}$ are expected, or (2) for lateral-intrusion observation wells, at the same altitude as the bottom of the corresponding production well's screened interval (fig. 8). Observation wells should therefore feature single, short screened intervals of no more than about $10 \mathrm{ft}$. Solid casing positioned below the screened interval - termed "cleanout" or "tailpipe" and commonly used with production wells — should not be used with observation wells because it would preclude effective purging before collection of groundwater chemical-quality samples. The well filter pack also should not extend any farther above the screened interval than needed to ensure that no grout enters the well. Particular care should be used that the annular space above the filter pack be uniformly sealed, grouted, or both to prevent overlying water of potentially different composition from entering the well.

Drilling of the observation wells will likely cause contamination of the aquifer. Because drilling disrupts the original structure of aquifer materials, well development (air lifting, pumping, backwashing, surging, or a combination of these) is generally used to restore the aquifer at and near screened intervals to its original condition. Because most aquifer sediments in the Virginia Coastal Plain are unconsolidated, hydraulic rotary drilling is most widely used. In addition to disruption of sediment structure, hydraulic rotary drilling typically introduces large volumes of drilling fluid to the borehole that differ in chemical composition from groundwater. Alternatively, rotosonic coring can minimize sediment disruption, but depending on borehole conditions can require introduction of large volumes of water, which may also differ in composition from groundwater. By either method, groundwater can be substantially altered by contamination with drilling fluids or introduced water, and also by contact with well construction materials (Claassen, 1982). Unlike production wells, however, continuous heavy pumping is not usually imposed on observation wells. Development of observation wells intended for collection of groundwater chemical-quality samples is therefore more critical than for production wells, or for observation wells intended solely for water-level monitoring or aquifer testing. The need cannot be overstated for thorough removal of drilling fluid or introduced water to enable collection of groundwater samples that are representative of the aquifer.

During hydraulic rotary drilling of the observation wells, the composition of drilling fluid should be controlled with regard to subsequent effects on well development. Fluid composition is controlled during drilling by the addition of bentonite and other substances to water circulating through the borehole and drilling system. Fluid viscosity is typically maintained high enough to stabilize the borehole and otherwise mechanically facilitate the drilling process. Although high viscosity minimizes fluid loss through the borehole wall, viscosity that is too high can heavily clog aquifer sediments (Claassen, 1982). As a result, thorough fluid removal during well development can become difficult to nearly impossible. Conversely, a less viscous fluid may penetrate the aquifer farther but can be more easily removed. Considerable knowledge and experience is needed to maintain drilling fluid at the optimal viscosity for both minimal sediment penetration during drilling and thorough removal during well development. By contrast, rotosonic coring is more advantageous than hydraulic rotary drilling because only water is introduced to the borehole and can be removed more easily than drilling fluid.

The most effective method of development and its required duration are likely to vary greatly among the observation wells. A record should be kept during drilling of the volume of drilling fluid loss or water introduction. Because of mixing and dispersion in the aquifer, and contact of groundwater with well construction materials, removal of a larger volume during well development will likely be needed in many cases. Various development techniques and measures of completeness are presented by Claassen (1982), Lapham and others (1997), and Wilde (1999). A record of pumping rates and durations along with monitoring of field parameters including turbidity, $\mathrm{pH}$, dissolved oxygen, specific conductance, and temperature, are considered basic documentation. Stabilization of field parameters to values representative of the aquifer is widely regarded as necessary to achieve adequate well development. 


\section{Sample Collection}

Following adequate development, groundwater chemicalquality samples can be collected from the observation wells. As with well drilling and development, a large body of literature - including Claassen (1982), Lapham and others (1997), and Wilde (1999)_-documents complex procedures and numerous considerations to successfully implement sample collection. Only selected aspects of particular importance to monitoring saltwater movement in the Virginia Coastal Plain aquifer system are summarized here.

Because groundwater can be substantially altered by contact with well construction materials, purging of the observation wells is needed immediately before each instance of sample collection. Stabilization of field parameters (turbidity, $\mathrm{pH}$, dissolved oxygen, specific conductance, and temperature) after removal of at least 3 well volumes is widely regarded as necessary to achieve adequate purging. Performance of the well during development - particularly pumping rates and associate water-level drawdown - can be used to estimate required pumping rates and durations for purging (Lapham and others, 1997). A record of field parameters, pumping rate and duration, pre-pumping static water level, and stabilized pumping water level is considered basic documentation.

Because of the proximity to saltwater, purging of the observation wells should incorporate additional measures.
Downward increasing salinity gradients have been widely observed by geophysical logging in unpumped observation wells containing saltwater in the Coastal Plain of Virginia. Stagnant water filling the well casing is sufficiently dense to stratify over time under the effect of gravity. The upper part of the casing contains relatively fresh water that is not representative of water in the aquifer and must be removed before sample collection. The position of the sampling pump should therefore be lowered with the declining water level during purging (fig. 9, left). Pump position should be maintained as closely as possible directly beneath the water level to ensure that water entering the screened interval from below displaces all stagnant water upward to the pump before sample collection. Incorrectly setting the pump to a position substantially below the stabilized water level throughout purging (fig. 9, right) will leave an overlying column of undisplaced stagnant water that can mix with water entering the pump during collection and alter sample composition.

Additional measures are necessary during purging of the observation wells, and subsequently as samples are collected, to ensure that the samples are representative of the aquifer. Groundwater resides in the confined aquifers of the Virginia Coastal Plain for tens of thousands of years (Nelms and others, 2003) and commonly contains little or no dissolved oxygen. Groundwater composition has resulted from chemical

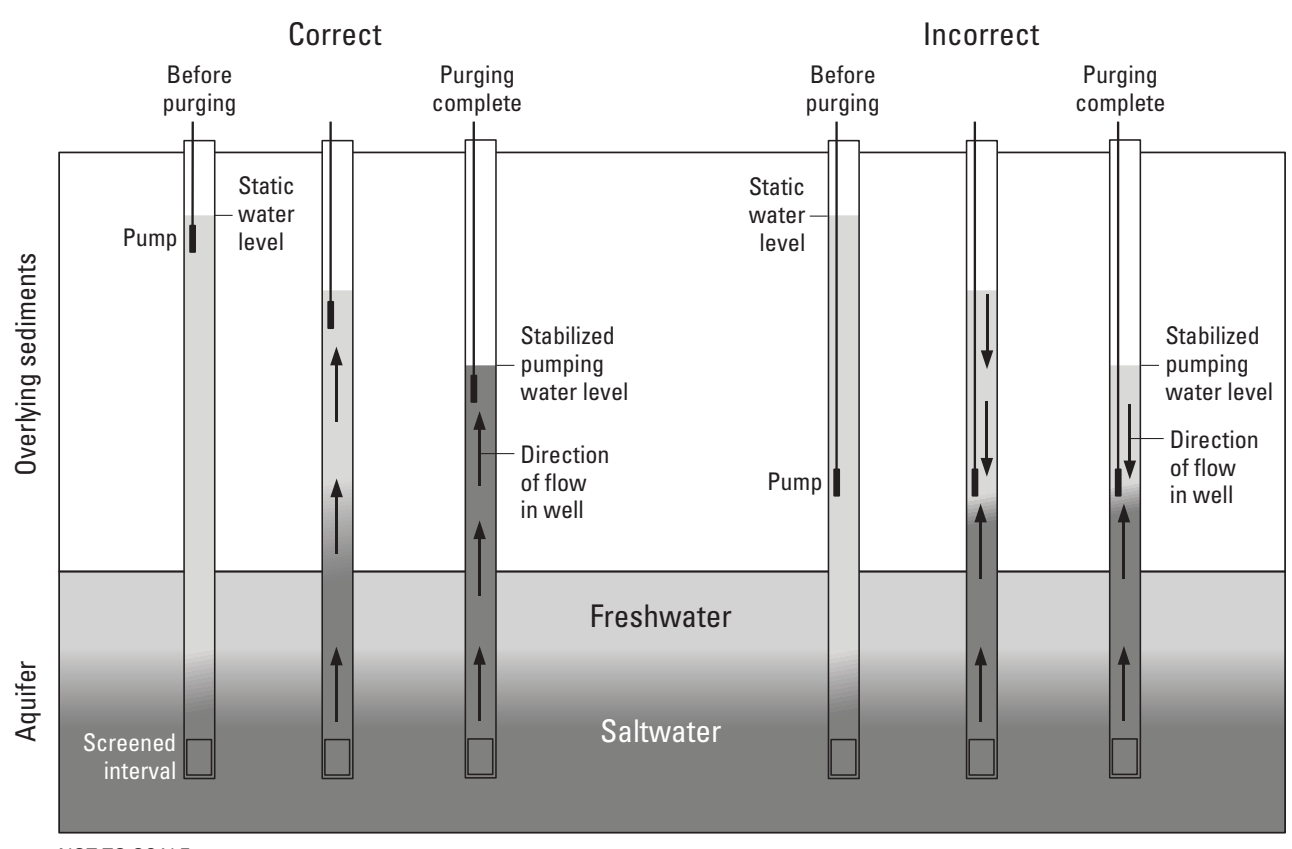

NOT TO SCALE

Figure 9. Pump placement and responses of observation wells to purging. Unpumped observation wells in proximity to saltwater widely contain stagnant water that has stratified over time. Fresh water is not representative of water in the aquifer and must be removed prior to sample collection. (Left) During purging, the sampling pump should be lowered with the declining water level so that water entering the screened interval displaces all stagnant water upward to the pump. (Right) Setting the pump below the stabilized water level throughout purging will leave overlying undisplaced stagnant water that can mix with and alter sample composition. 
equilibria established largely in the absence of oxygen, but can be substantially altered by exposure to atmospheric oxygen. Pumping equipment should therefore be configured to measure field parameters in water kept in isolation from the atmosphere, such as using a flow-through chamber (Wilde, 1999). Chemical equilibria can also be altered by changes in temperature. Care should be used to not subject pump hoses and other equipment to conditions that would greatly affect water temperature, such as exposure to direct sunlight or other sources of heat.

Upon completion of purging the observation wells, a final set of field-parameter measurements should be recorded as groundwater chemical-quality samples are immediately collected. Sample containers should be filled in continuum with purging while stable flow is maintained (Wilde, 1999). Any interruption or change in flow rate can potentially alter hydraulic conditions between the aquifer and observation well. Water-level recovery or additional decline can induce turbulence; increase dissolved oxygen, turbidity, or both; alter other field parameters; and otherwise affect sample composition. Optimally, pump hoses can be configured to include a side discharge from which sample water can be easily obtained as conditions are kept uniform. Sample water should be filtered so that only dissolved species are analyzed. A membrane having a 0.45 -micron pore size is generally adequate for analysis of major ions (see "Sample Analysis" section). In-line capsule filters avoid any additional handling of sample water during collection. Sample water should receive minimal atmospheric contact while filling containers and promptly using preservation that follow laboratory protocols. Because carbonate species are among those constituents that can be altered by atmospheric contact and temperature changes, alkalinity should be promptly determined in the field as part of sample collection. Inflection-point titration should be completed because fixed endpoint titration can lead to errors (Hem, 1985).

In addition to routine samples as described above, collection of quality-control samples should be considered. Samplecollection and analysis procedures can be evaluated using various replicate, spike, or blank samples, or a combination of these, but is beyond the scope presented here. Approaches to designing a sampling quality-control program are discussed by Wilde (1999).

\section{Sampling Frequency}

In the broadest terms, groundwater chemical-quality samples need to be collected from the observation wells frequently enough to accurately characterize the range and variability of chloride concentration that results from saltwater movement. In proximity to active groundwater-production wells, vertical upconing coupled with lateral intrusion can result in a composite chloride-concentration trend (see "Chloride-Concentration Trends" section). More specifically, therefore, sampling frequency needs to enable upconing to be distinguished from lateral intrusion for the relative immediacy and permanence of saltwater contamination to be assessed (see "Upconing and Lateral Intrusion" section).

Optimally efficient sampling of observation wells can in theory be timed with withdrawal from their corresponding production wells, if responses in chloride concentrations can be reliably predicted. Seasonal upconing cycles would require relatively frequent sample collection, whereas fewer samples may be needed during longer continuously active or dormant periods (fig. 6). Relations between observation wells and their corresponding production wells cannot be known, however, without an established record of cause-and-effect behavior. In many areas, sampling frequency also needs to account for concentration fluctuations that evolve dynamically in response to multiple neighboring production wells that are operated at different times, but which may not be entirely known (see "Chloride-Concentration Trends" section).

In light of the above - and the seasonal nature of many groundwater withdrawals in response to cyclical water demands - a sample-collection frequency of four times per year should be considered initially for newly established observation wells. Upconing cycles can thereby probably be identified in most cases. Quarterly sampling would initially be used at both upconing and lateral-intrusion observation wells. Upconing wells are to be collocated purposefully with corresponding production wells so as to exhibit effects of upconing (see "Locations" section). Although locations of lateral intrusion wells are projected to avoid upconing effects from corresponding production wells, other neighboring production wells can potentially impose effects that are not initially known. Complete records of withdrawals from corresponding production wells and neighboring production wells are critical to enable cause-and-effect relations with chloride-concentration fluctuations to be discerned.

Where upconing is active, sampling too infrequently would likely not distinguish individual upconing cycles. Depending on the timing, infrequent sampling also has the potential to produce a false chloride-concentration trend (fig. 6). Adjustments to the quarterly frequency can potentially be considered, however, to optimize sampling efficiency among individual observation wells. If a strong record of cause-and-effect behavior can be established, responses in chloride concentrations may be reliably predicted and thereby enable sampling to be timed with withdrawal. Future prospects for any additional withdrawals that could alter conditions from the historical trend must also be considered.

\section{Sample Analysis}

Concentrations of chloride are of primary concern with regard to movement of saltwater in the Virginia Coastal Plain aquifer system (see "Introduction" section). Compared to the SMCL of $250 \mathrm{mg} / \mathrm{L}$, some chloride concentrations in groundwater are as much as that of seawater $(19,000 \mathrm{mg} / \mathrm{L})$ and greater (McFarland, 2010). The potential for chloride contamination because of saltwater movement is therefore substantial. 
Chloride is among several ionic species that dominate the chemical composition of groundwater in the Virginia Coastal Plain. Major cations include calcium, magnesium, sodium, and potassium. Major anions in addition to chloride include bicarbonate, carbonate, and sulfate; and in some areas also fluoride and bromide. As exemplified by the Potomac aquifer, primarily sodium and bicarbonate are present at small concentrations in the western and central parts of the aquifer system (McFarland 2010). Eastward across the saltwatertransition zone, however, total ion concentration increases markedly (fig. 3) and chloride supersedes bicarbonate as the dominant anion.

In light of the above, analysis of all major cations and anions should be considered for groundwater samples initially collected from newly established observation wells. The dominant chemical composition of groundwater at each well must be determined to establish its relative position within the saltwater-transition zone. Concentrations of all major ions also provide a valuable means of data quality control. Calculation of sample charge balance is widely used to evaluate the analytical accuracy of major-ion concentrations (Hem, 1985). For all major ions to be accurately accounted for, the sum of cation concentrations should be about equal to that of anion concentrations, both in units of milliequivalents per liter (meq/L) to account for different electrical charges and molecular weights among ions. The percent relative difference between cations and anions is calculated as:

$$
\frac{\text { sum of cations }(\mathrm{meq} / \mathrm{L})-\text { sum of anions }(\mathrm{meq} / \mathrm{L})}{\text { sum of cations }(\mathrm{meq} / \mathrm{L})+\text { sum of anions }(\mathrm{meq} / \mathrm{L})} \times 100
$$

A margin of error of within plus or minus 5 percent is generally considered acceptable. Values of greater magnitude indicate that either one or more concentration values are erroneous, or that one or more unanalyzed ionic species are present at substantial concentrations. Several measures are necessary during sample collection for major-ion concentrations to result in a correct charge balance and reflect chemical equilibria that are representative of the aquifer (see "Sample Collection" section).

Assuming that newly established observation wells will be sampled initially on a quarterly basis (see "Sampling Frequency" section), analysis of all major ions should be considered for the first year of sample collection. Adjustments to analyses of samples collected from individual wells can potentially be considered once the dominant chemical composition at each well is established. Chloride is considered to be a conservative constituent that generally does not undergo chemical reactions in groundwater, which would alter its concentration over time. Instead, changes in chloride concentration are likely to result primarily from movement of saltwater rather than alteration of dominant chemical composition. Analysis of chloride - along with field parameters needed to ensure proper sample collection (see "Sample Collection" section) - may therefore be adequate to monitor saltwater movement during a period of years to decades.
A relation of chloride concentration to specific conductance may also potentially provide a basis for adjustments to sample analyses. A Locally Weighted Scatterplot Smoothing (LOWESS) regression (Helsel and Hirsch, 2002) indicated such a relation among 1,658 historical groundwater samples collected in the Virginia Coastal Plain (McFarland, 2010). Because specific conductance is a function of total ion concentration, and saltwater is dominated by sodium cations and chloride anions, specific conductance is directly proportional to chloride concentration. If relations between chloride concentration and specific conductance among individual observation wells can be demonstrated, specific conductance can potentially be considered as a surrogate for chloride concentration to monitor saltwater movement at each well during a period of years to decades.

As an alternative to sample collection, specific conductance can be continuously monitored in appropriately instrumented wells. Determining changes in groundwater salinity on this basis, however, is dependent on the hydraulic connection between the aquifer and unpumped well. Any trend in specific conductance in the well can potentially be obscured by stratification of stagnant water (see "Sample Collection" section). As another nonsampling alternative, time-domain electromagnetic-induction well logging has been successfully used to determine changes in groundwater salinity (Prinos, 2014). Induction logging has the advantage of detecting changes in the bulk conductivity of the aquifer across a diameter of as much as several feet centered on the well. Wells must be cased only with non-conductive materials, however, and logged frequently enough to distinguish upconing cycles. In addition to any conductance-based form of monitoring, chloride concentrations may still be required by regulatory policy to demonstrate adherence to the chloride SMCL.

\section{Limitations and Constraints}

Several factors limit and constrain monitoring the movement of saltwater in the Virginia Coastal Plain aquifer system and must be recognized for effective implementation of the strategy presented here. Assessing relative needs for monitoring among groundwater-production wells is dependent upon the accuracy of groundwater chloride iso-concentration surfaces along with variations among aquifer hydraulic conductivities, and well withdrawal rates and screenedinterval lengths. Monitoring is further limited by incomplete withdrawal information. Construction of observation wells is also dependent upon chloride-surface accuracy, and can be constrained by the lateral extent of upconing, physical impediments, aquifer depths, and neighboring production wells.

\section{Classification of Production Wells}

Out of 612 groundwater-production wells, 81 wells are identified from which chloride concentrations are most likely to increase above the $250-\mathrm{mg} / \mathrm{L}$ chloride SMCL. The 
production wells are classified based on vertical and lateral distances to previously mapped (McFarland, 2010) groundwater chloride iso-concentration surfaces (see "Proximity of Groundwater-Production Wells to Saltwater" section).

Potential locations and depths of observation wells are also based on depths and directions to the chloride surfaces (see "Locations" section). Monitoring is therefore dependent upon the accuracy of the chloride surfaces.

The chloride surfaces are based on 6,650 groundwatersample chloride concentrations that originate from diverse historical data sources during 1906-2007 (McFarland, 2010). Potential data errors include well construction; sample collection, preservation, and analysis; typographic mistakes; and other reporting problems. The chloride surfaces are also interpolated across areas between sample locations and, in some instances, extrapolated beyond the area spanned by samples. The surfaces were manually generated to be consistent with the sample chloride concentrations, but are not wholly constrained by them. A general indication is therefore represented of different groundwater chloride concentrations at various altitudes within the Coastal Plain sediments.

As a means to prioritize relative needs for monitoring, production wells are listed in order of vertical proximity to the $250-\mathrm{mg} / \mathrm{L}$ chloride surface (table 1 , attachment 1 ). Some production wells in similar proximity, however, can differ in other respects. Among these, aquifer hydraulic conductivities and well rates of withdrawal vary widely. A production well in a highly conductive aquifer, having a large withdrawal rate, or both may be considered a higher priority for monitoring than a production well in the same proximity to saltwater, but in a less conductive aquifer or having a smaller withdrawal rate.

In addition, some wells in similar proximity to saltwater can produce water having substantially contrasting chloride concentrations. Vertical and lateral distances of production wells to chloride surfaces are referenced to the bottoms of screened intervals, which are considered to be the open part of each well in closest proximity to saltwater. Chloride concentrations in groundwater intercepted by production wells, however, are also dependent on well screened-interval lengths. Screened intervals intersect varying thicknesses of the aquifer, across which groundwater can be relatively fresh compared to that at the bottoms of screens. Wells with short screened intervals intercept isolated parts of the aquifer having relatively uniform chloride concentrations. By contrast, wells with long or multiple screened intervals intercept greater thicknesses of the aquifer across which groundwater of varying chloride concentrations enters the wells at different altitudes and is mixed. Proportions of mixing between water of contrasting composition can also vary over time as withdrawal rates vary (Yager and Heywood, 2014).

Not all groundwater-production wells have been accounted for here. Thousands of production wells are widely distributed throughout the Virginia Coastal Plain aquifer system, and are continually evolving as new wells are constructed and existing wells are taken into and out of service. Most production wells provide small individual water supplies, and less than 1 percent of groundwater withdrawals are large enough to be subject to requirements for reporting to the VA DEQ. Among these, some lack complete information on withdrawal rates, location, and well construction. Additional large withdrawals are also likely being made that are wholly unknown, as has been indicated at some locations by spurious fluctuations in groundwater levels. Although the VA DEQ directs considerable resources at maintaining records of the largest withdrawals, fully accounting for every production well is probably unrealistic.

Considering the above, monitoring saltwater movement can be anticipated to result in some spurious changes in groundwater chloride concentration that do not seem attributable to known withdrawals. Efforts should be made to identify unknown production wells in proximity that could account for the concentration changes. Complete records of withdrawals among neighboring production wells are critical to enable cause-and-effect relations with chloride-concentration fluctuations to be discerned. In some cases, however, an element of doubt may necessarily persist.

\section{Construction of Observation Wells}

Conditions at and near some groundwater-production wells potentially constrain the construction of corresponding observation wells. Conditions at each location will likely vary and require adapting to on a case-by-case basis, and are not addressed individually here. Not every circumstance can be fully anticipated, but many may be approached by following the general guidelines below.

Upconing observation wells should be as close as possible to corresponding production wells. The lateral extent of upconing is unknown, but probably variable. Upconing is theorized, however, to be centered on each production well during withdrawal. Upconing observation wells need therefore to also be centered to isolate chloride-concentration fluctuations resulting from the corresponding production well and avoid the effects of hydraulic interactions with neighboring production wells. Care should also be used during drilling, however, so that boreholes do not vertically deviate to the extent that they would intercept and damage the nearby production wells.

Construction of lateral-intrusion observation wells may also be precluded at some of their projected locations. Observation-well locations are projected across open water from parts of the city of Virginia Beach, Va., and Lancaster and Mathews Counties, Va. Offshore drilling may be impractical or cost-prohibitive. Elsewhere, other water bodies and preexisting structures or activities, neighboring production wells, restricted access, or other impediments may make some locations infeasible. Projected locations are therefore best regarded as a general guide that should be anticipated as requiring adjustment. Keeping in mind the basis for the projected location directions and distance (see "Locations" 
section), adjustment to either distance, direction, or both may be needed.

In addition to their locations, the depths of some upconing or lateral-intrusion observation wells may require adjustment relative to their positions within the aquifer system. Specified depths for observation wells (see "Construction and Development" section) will in most cases be positioned in the same aquifers as their corresponding production wells, requiring no adjustment. Chloride iso-concentration surfaces, however, pass through both aquifers and confining units. Because of variations in aquifer dip, specified depths for some observation wells may be determined during drilling to be marginally above or below the aquifer of their corresponding production wells (fig. 10). In such cases, observation-well depths should be adjusted to be within the same aquifer as corresponding production wells, but remaining as close to the originally specified depths as possible.

In place of new construction, existing unused wells can potentially be considered to adapt as observation wells for monitoring saltwater movement. The basis for location and construction of observation wells presented here, however, should be kept in mind in assessing the suitability of existing wells for monitoring. Any differences of existing wells from this basis should also be kept to a minimum, and would require accounting for in interpreting how changes in chloride concentrations reflect saltwater movement.

To the extent possible, observation wells should be located and constructed to identify changes in groundwater chloride concentration directly associated with their corresponding individual production wells. Some production wells can be in proximity or collocated, however, including at several known locations in the counties of James City and Lancaster, Va., and the cities of Chesapeake, Portsmouth, and Virginia Beach, Va. (fig. 1, pl. 1). Upconing resulting from multiple neighboring production wells is theorized to produce a dynamically evolving composite of chloride-concentration fluctuations that does not correspond with the withdrawal from any single production well (see "Saltwater Movement" section). An additive effect on lateral intrusion can also potentially take place at the relatively remote distance of $1 \mathrm{mi}$ without corresponding directly to withdrawal from any one of the wells. Neither upconing nor lateral-intrusion observation wells may be able to distinguish chloride-concentration changes resulting from individual production wells at these locations.

Given the above, a modified approach may be needed in some cases to construct observation wells with the objective of determining the localized net effect of neighboring production wells on changes in chloride concentration. A single upconing monitoring well would be collocated among the production wells and completed at about the altitude of the $250-\mathrm{mg} / \mathrm{L}$ chloride iso-concentration surface (fig. 11, left side). A lateral-intrusion observation well would also be about centrally located among locations projected from the production wells. If screened-interval bottoms of all production wells are positioned at similar altitudes, a single lateral-intrusion observation well can be completed at the same altitude. If the bottoms of the production wells have substantially varying altitudes, however, more than one lateral-intrusion observation well may need to be completed at the appropriate altitudes (fig. 11, right side). This modified approach should also account for (1) which of the production wells are active, likely to be active (versus those going unused on an indefinite basis), or both; and (2) any additional neighboring production wells close enough to affect chloride concentrations.

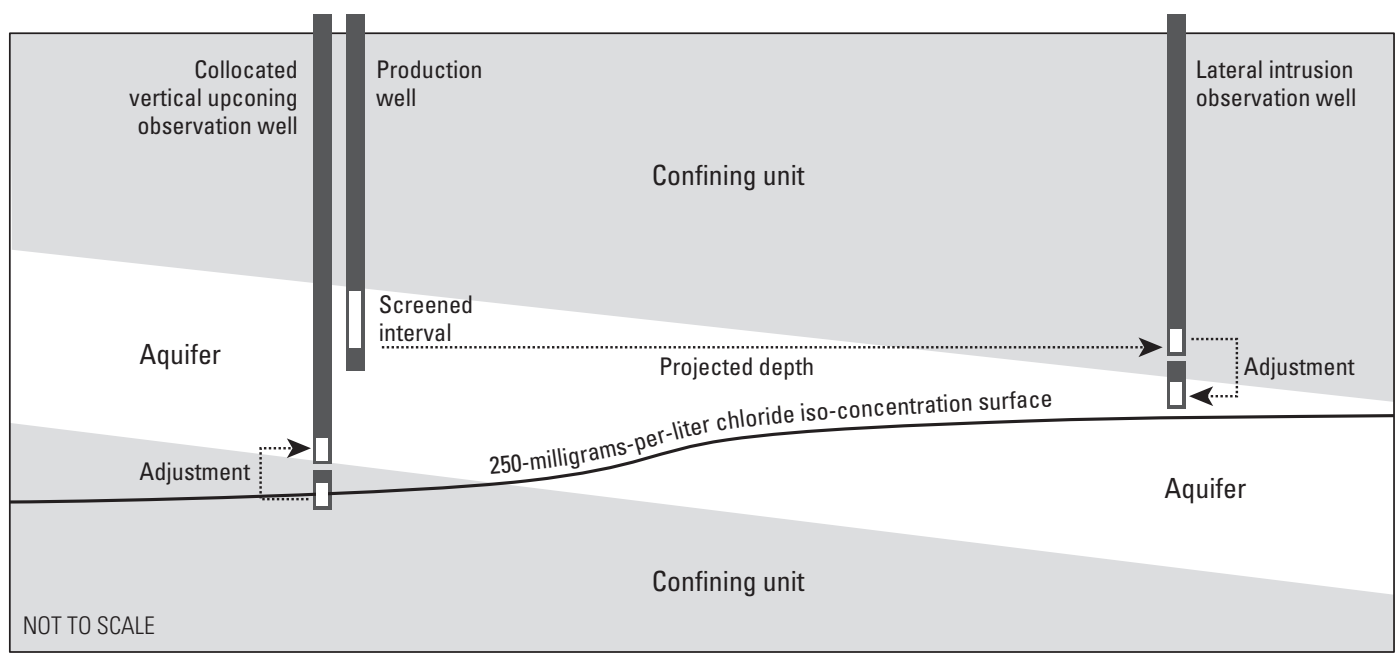

Figure 10. Adjustments to observation-well depths relative to positions within the aquifer system. Chloride iso-concentration surfaces pass through both aquifers and confining units. Depths for observation wells that are above or below the aquifer of their corresponding production wells should be adjusted to be within the same aquifer, but remaining as close to the originally specified depths as possible. 


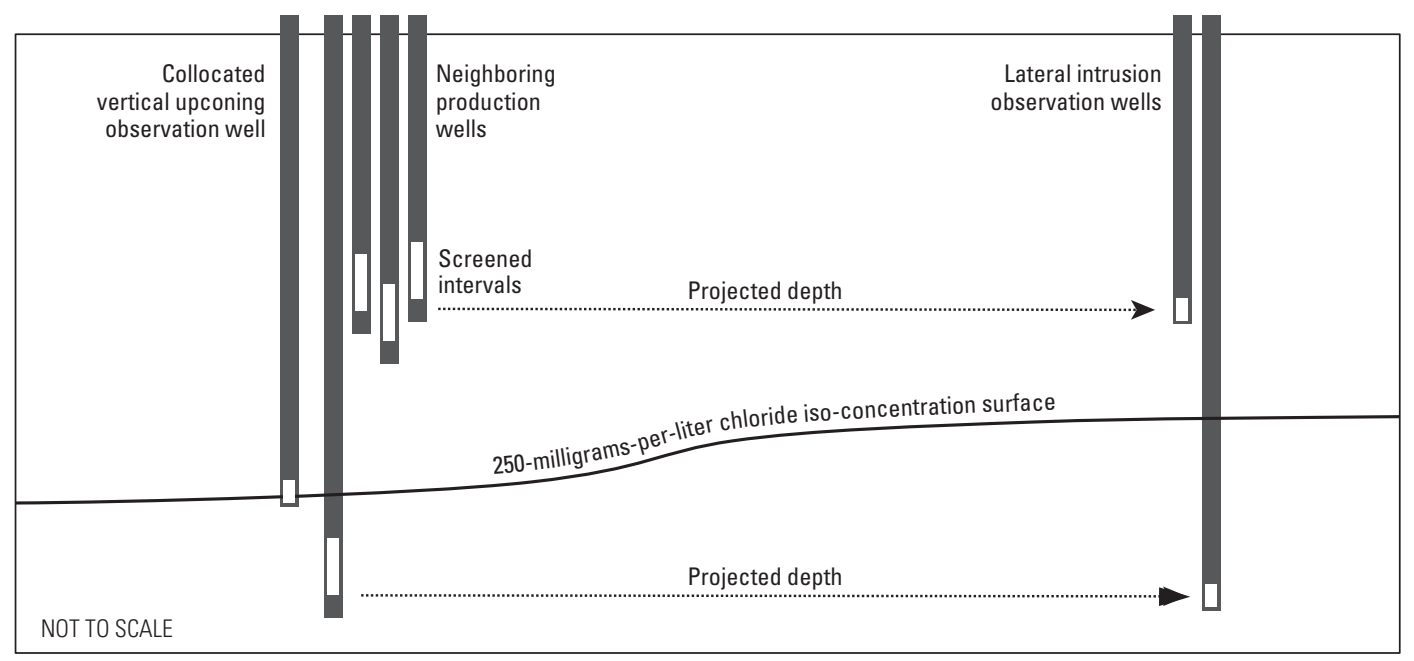

Figure 11. Generalized spatial relations of observation wells to multiple neighboring groundwater-production wells. Observation wells may be unable to distinguish chloride-concentration changes resulting from individual production wells, but can be constructed to determine their localized net effect. (Left) A single upconing monitoring well is collocated among the production wells and completed at the approximate altitude of the 250-milligramsper-liter chloride iso-concentration surface. (Right) Lateral intrusion observation wells are projected from the production wells. A single lateral intrusion observation well can be completed at the same altitude as screenedinterval bottoms of production wells positioned at similar altitudes. Additional lateral intrusion observation wells may be needed for production wells having screened-interval bottoms with substantially varying altitudes.

\section{Summary and Conclusions}

Groundwater withdrawal has created the potential for movement of saltwater in the Virginia Coastal Plain aquifer system. Monitoring saltwater movement is needed to detect increases in chloride concentration before groundwaterproduction wells become contaminated. The saltwater-transition zone and the distribution of groundwater withdrawals are complex, which poses a substantial challenge for effective monitoring of saltwater movement. To assess the immediacy and permanence of contamination, the manner of saltwater movement must also be determined by distinguishing vertical upconing from lateral intrusion. An investigation was therefore undertaken during 2014 by the U.S. Geological Survey in cooperation with the Virginia Department of Environmental Quality (VA DEQ), to develop a conceptual framework and monitoring strategy for saltwater movement in the Virginia Coastal Plain aquifer system. The framework and strategy provides a sound scientific understanding of saltwater movement and guidance to implement a monitoring program.

A conceptual framework synthesizes previous studies to provide an understanding of conditions, processes, and relations of saltwater to groundwater withdrawal. Hydrochemical evidence indicates that saltwater in the aquifer system originated primarily from seawater repeatedly emplaced within aquifer sediments during the past about 65 million years, and was subsequently flushed by eastward and downward flowing fresh groundwater. Flushing has been impeded, however, in low hydraulic conductivity sediments filling the Chesapeake Bay impact crater, where seawater has been retained. The resulting saltwater-transition zone exhibits a warped and steeply mounded dome shape about centered on the impact crater that is flanked by a nearly level and shallow plateau shape to the southeast. Despite that groundwater withdrawal has redirected the hydraulic gradient landward, the saltwatertransition zone has not moved because withdrawn water is released from aquifer storage rather than displaced across regionally appreciable distances.

Historical groundwater chemical-quality samples exhibit fluctuating chloride concentrations. Numerous instances of intermittent localized upconing beneath individual groundwater-production wells are theorized to reverse within weeks to months of a decrease or cessation of withdrawal. By contrast, lateral intrusion in the form of horizontal displacement of groundwater toward a production well probably takes several decades or more to cross distances of about 1 mile. Upconing is relatively immediate, but reversible, whereas lateral intrusion will continue under the regionally landward hydraulic gradient to slowly, but permanently reposition the saltwater-transition zone.

Upconing coupled with lateral intrusion is theorized to produce a composite chloride-concentration trend. Upconing cycles result from withdrawals that vary widely over time in response to changing water demands. Concentration fluctuations of as much as several hundred milligrams per liter $(\mathrm{mg} / \mathrm{L})$ increase from and decrease to a baseline concentration, which because of lateral intrusion increases by a smaller amount during a period of years to decades. A dynamically evolving composite of concentration fluctuations can result from complex local hydraulic interactions among neighboring 
production wells, some of which may be unknown. Conversely, groundwater chloride concentrations can be nearly constant where unaffected by upconing, or where withdrawal is kept constant during periods of years to decades.

A strategy for monitoring saltwater movement in the Virginia Coastal Plain aquifer system is based on spatial relations between the saltwater-transition zone and 612 groundwaterproduction wells that were regulated by the VA DEQ during 2013. The vertical position and lateral distance and direction of the bottom of each production well's screened interval was calculated relative to previously mapped $250-\mathrm{mg} / \mathrm{L}$ and 1,000-mg/L groundwater chloride iso-concentration surfaces. Spatial analysis identified 81 production wells completed in the Yorktown-Eastover and Potomac aquifers that are positioned in closest proximity to the $250-\mathrm{mg} / \mathrm{L}$ chloride surface, and from which chloride concentrations are most likely to increase above the U.S. Environmental Protection Agency's 250-mg/L secondary maximum contaminant level. Observation wells are specified to distinguish vertical upconing from lateral intrusion among individual production wells. To monitor upconing, an observation well is to be collocated with each production well and completed at about the altitude of the $250-\mathrm{mg} / \mathrm{L}$ chloride isoconcentration surface. To monitor lateral intrusion, a potential location of an observation well is projected from the bottom of each production well's screened interval, in the lateral direction to the underlying chloride surface to a distance of $1 \mathrm{mi}$.

The following aspects of observation-well construction and sampling are of particular importance to monitoring saltwater movement in the Virginia Coastal Plain aquifer system:

1. Observation wells should feature screened intervals generally of no more than 10 feet that isolate distinct parts of the aquifer.

2. Observation wells should be thoroughly developed to remove drilling fluid or introduced water.

3. Before each collection of groundwater chemical-quality samples, observation wells should be purged by lowering the position of the sampling pump as closely as possible directly beneath the declining water level so as to fully displace all stratified saltwater in the well casing upward to the pump.

4. In order to maintain chemical equilibria that are representative of the aquifer, field parameters should be measured during purging from water kept in isolation from the atmosphere and conditions that would greatly affect water temperature.

5. Sample containers should be filled with filtered water having minimal atmospheric contact while stable flow is maintained without interruption or change in flow rate.

6. Inflection-point titration for alkalinity should be completed in the field.

7. In order to distinguish individual upconing cycles and not potentially produce a false chloride-concentration trend, a sample-collection frequency of four times per year should be considered initially for newly established upconing and lateral-intrusion observation wells.

8. Once responses in chloride concentrations to changes in production-well withdrawal can be reliably predicted, observation-well sampling can be more optimally timed with production-well withdrawal.

9. Analysis of major ions - including calcium, magnesium, sodium, and potassium cations and chloride, bicarbonate, carbonate, sulfate, fluoride, and bromide anionsshould be considered for groundwater samples initially collected for the first year from newly established observation wells. Concentrations of major ions (1) determine the dominant chemical composition of groundwater at each well, (2) establish its relative position within the saltwater-transition zone, and (3) provide data-quality control by calculation of sample charge balance.

10. Once the dominant chemical composition at each well is established, analysis of chloride along with field parameters may be adequate during periods from years to decades.

11. Specific conductance can potentially be considered as a surrogate for chloride concentration depending on regulatory policy.

The following factors limit and constrain monitoring saltwater movement in the Virginia Coastal Plain aquifer system, and must be recognized for effective implementation of the monitoring strategy:

1. Relative needs for monitoring among groundwaterproduction wells and construction of observation wells are dependent upon the accuracy of groundwater chloride iso-concentration surfaces.

2. Production wells in similar proximity to saltwater can differ in aquifer hydraulic conductivities, and well rates of withdrawal and screened-interval lengths.

3. Only production wells making withdrawals large enough to be subject to reporting requirements to the VA DEQ, and having complete information, have been accounted for.

4. Undocumented production wells are numerous and widespread, and can result in spurious changes in groundwater chloride concentration.

5. Upconing observation wells should be as close as possible to corresponding production wells so long as boreholes do not vertically deviate during drilling to intercept and damage the production wells.

6. Construction of some lateral-intrusion observation wells may be precluded by various impediments at their projected locations and require adjustment to either the projected distance, direction, or both. 
7. Specified depths of some upconing or lateral-intrusion observation wells may be marginally above or below the aquifer of their corresponding production wells, and require adjustment to be within the same aquifer.

8. Existing unused wells can be potentially adapted as observation wells for monitoring saltwater movement so long as differences from specified observation-well locations and construction are kept to a minimum, and are accounted for in interpreting changes in chloride concentrations.

9. Where multiple production wells are in proximity or collocated, neither upconing nor lateral-intrusion observation wells may be able to distinguish chloride concentration changes resulting from individual production wells. A modified approach can be used, however, to determine the net effect of neighboring production wells on changes in chloride concentration. More than one lateral-intrusion observation well may be required depending on whether production-well screened intervals are similarly positioned.

\section{References Cited}

Barlow, P.M., 2003, Ground water in freshwater-saltwater environments of the Atlantic Coast: U.S. Geological Survey Circular 1262, $113 \mathrm{p}$.

Bradley, R.S., 1999, Paleoclimatology: Burlington, Mass., Harcourt/Academic Press, 613 p.

Cederstrom, D.J., 1943, Chloride in ground water in the Coastal Plain of Virginia: Virginia Geological Survey Bulletin 58, $36 \mathrm{p}$.

Claassen, H.C., 1982, Guidelines and techniques for obtaining water samples that accurately represent the water chemistry of an aquifer: U.S. Geological Survey Open-File Report 82-1024, 49 p.

Code of Virginia, Title 62.1, Chapter 25, The ground water management act of 1992 .

Eggleston, Jack, and Pope, Jason, 2013, Land subsidence and relative sea-level rise in the southern Chesapeake Bay region: U.S. Geological Survey Circular 1392, 30 p. [Also available at http://dx.doi.org/10.3133/cir1392.]

Ghyben, W.B., 1888, Nota in verband met de voorgenomen putboring nabij Amsterdam: Tijdschrift van Let Koninklijk Inst. Van Ing.
Harsh, J.F., and Laczniak, R.J., 1990, Conceptualization and analysis of ground-water flow system in the Coastal Plain of Virginia and adjacent parts of Maryland and North Carolina: U.S. Geological Survey Professional Paper 1404F, 100 p.

Heath, R.C., 1987, Basic ground-water hydrology: U.S. Geological Survey Professional Paper 2220, 84 p.

Helsel, D.R., and Hirsch, R.M., 2002, Statistical methods in water resources: U.S. Geological Survey Techniques of Water-Resources Investigations, book 4, chap. A3, 510 p.

Hem, J.D., 1985, Study and interpretation of the chemical characteristics of natural water: U.S. Geological Survey Water-Supply Paper 2254, 263 p.

Henry, H.R., 1960, Salt water intrusion into coastal aquifers: International Association of Scientific Hydrology, Publication 52, p. 478-487.

Herzberg, Alexander, 1901, Die Wasserversorgung einiger Nordseebader: J. Gasbeleucht, Wasserversorg, 44, p. 815-819.

Heywood, C.E., and Pope, J.P., 2009, Simulation of groundwater flow in the Coastal Plain aquifer system of Virginia: U.S. Geological Survey Scientific Investigations Report 2009-5039, 115 p.

Lacombe, P.J., and Carleton, G.B., 2002, Hydrogeologic framework, availability of water supplies, and saltwater intrusion, Cape May County, New Jersey: U.S. Geological Survey Water-Resources Investigations Report 01-4246, $151 \mathrm{p}$.

Lapham, W.W., Wilde, F.D., and Koterba, M.T., 1997, Guidelines and standard procedures for studies of ground-water quality: selection and installation of wells, and supporting documentation: U.S. Geological Survey Water-Resources investigations Report 96-4233, 110 p.

Larson, J.D., 1981, Distribution of saltwater in the Coastal Plain aquifers of Virginia: U.S. Geological Survey OpenFile Report 81-1013, 25 p.

Lichtler, W.F., and Wait, R.L., 1974, Summary of the groundwater resources of the James River basin, Virginia: U.S. Geological Survey Open-File Report 74-139, 54 p.

Manheim, F.T., and Horn, M.K., 1968, Composition of deeper subsurface waters along the Atlantic continental margin: Southeastern Geology, v. 9, no. 4, p. 215-236.

McFarland, E.R., 2010, Groundwater-quality data and regional trends in the Virginia Coastal Plain, 1906-2007: U.S. Geological Survey Professional Paper 1772, 86 p. 
McFarland, E.R., 2013, Sediment distribution and hydrologic conditions of the Potomac aquifer in Virginia and parts of Maryland and North Carolina: U.S. Geological Survey Scientific Investigations Report 2013-5116, 67 p.

McFarland, E.R., and Bruce, T.S., 2005, Distribution, origin, and resource-management implications of ground-water salinity along the western margin of the Chesapeake Bay impact structure in eastern Virginia, in Horton, J.W., Jr., Powars, D.S., and Gohn, G.S., eds., Studies of the Chesapeake Bay impact structure-The USGS-NASA Langely corehole, Hampton, Virginia, and related coreholes and geophysical surveys: U.S. Geological Survey Professional Paper 1688, chap. K, 32 p.

McFarland, E.R., and Bruce, T.S., 2006, The Virginia Coastal Plain hydrogeologic framework: U.S. Geological Survey Professional Paper 1731, 118 p.

Meisler, Harold, 1989, The occurrence and geochemistry of salty ground water in the northern Atlantic Coastal Plain: U.S. Geological Survey Professional Paper 1404-D, 51 p.

Meng, A.A., III, and Harsh, J.F., 1988, Hydrogeologic framework of the Virginia Coastal Plain: U.S. Geological Survey Professional Paper 1404-C, 82 p.

Mixon, R.B., Berquist, C.R., Jr., Newell, W.L., Johnson, G.H., Powars, D.S., Schindler, J.S., and Rader, E.K., 1989, Geologic map and generalized cross sections of the Coastal Plain and adjacent parts of the Piedmont, Virginia: U.S. Geological Survey Miscellaneous Investigations Series Map I-2033, scale 1:250,000.

Nelms, D.L., Harlow, G.E., Jr., Plummer, L.N., and Busenberg, Eurybiades, 2003, Aquifer susceptibility in Virginia, 1998-2000: U.S. Geological Survey WaterResources Investigations Report 03-4278, 58 p.

Peltier, W.R., 1994, Ice age paleotopography: Science, v. 265, no. 5169, p. 195-201.

Pope, J.P., and Burbey, T.J., 2004, Multiple-aquifer characterization from single borehole extensometer records: Groundwater, v. 42 , no. 1 , p. $45-58$.

Pope, J.P., McFarland, E.R., and Banks, R.B., 2008, Private domestic-well characteristics and the distribution of domestic withdrawals among aquifers in the Virginia Coastal Plain: U.S. Geological Survey Scientific Investigations Report 2007-5250, 47 p.

Powars, D.S., 2000, The effects of the Chesapeake Bay impact crater on the geological framework and correlation of hydrogeologic units of southeastern Virginia, south of the James River: U.S. Geological Survey Professional Paper 1622, 53 p., 1 pl.
Powars, D.S., and Bruce, T.S., 1999, The effects of the Chesapeake Bay impact crater on the geological framework and correlation of hydrogeologic units of the lower York-James Peninsula, Virginia: U.S. Geological Survey Professional Paper 1612, 82 p., 9 pls.

Prinos, S.T., 2014, Using state-of-the-art technology to evaluate saltwater intrusion in the Biscayne aquifer of Miami-Dade County, Florida: U.S. Geological Survey Fact Sheet 2014-3050, 6 p. [Also available at http://dx.doi.org/10.3133/fs20143050.]

Sanford, Samuel, 1913, The underground water resources of the Coastal Plain Province of Virginia: Virginia Geological Survey Bulletin 5, $361 \mathrm{p}$.

Sanford, W. E., 2003, Heat flow and brine evolution following the Chesapeake Bay Bolide Impact. Journal of Geochemical Exploration, v. 78-79, p. 243-247.

Sanford, W. E., 2005, Simulation of the hydrothermal response to the Chesapeake Bay bolide impact, Geofluids, v. 5, p. 185-201.

Sanford, W.E., Voytek, M.A., Powars, D.S., Jones, B.F., Cozzarelli, I.M., Cockell, C.S., and Eganhouse, R.P., 2009, Pore-water chemistry from the ICDP-USGS corehole in the Chesapeake Bay impact structure-Implications for paleohydrology, microbial habitat, and water resources: Geological Society of America Special Paper 458, p. 867-890.

Sanford, W.E, Doughten, M.W., Coplen, T.B., Hunt, A.G., and Bullen, T.D., 2013, Evidence for high salinity of Early Cretaceous sea water from the Chesapeake Bay crater: Nature, v. 503, p. 252-256.

U.S. Environmental Protection Agency, 1990, Secondary maximum-contaminant levels (section 143.3 of part 143, National secondary drinking water regulations): U.S. Code of Federal Regulations, Title 40, Parts 100 to 149, revised as of July 1, 1990, p. 674.

Wilde, F.D., 1999, National field manual for the collection of water-quality data, collection of water samples: U.S. Geological Survey Techniques of Water-Resources Investigations, book 9, chapter A4, $103 \mathrm{p}$.

Yager, R. M., and Heywood, C.E., 2014, Simulation of the effects of seasonally varying pumping on intraborehole flow and the vulnerability of public-supply wells to contamination: Groundwater, v. 52, no. 1, p. 40-52. 


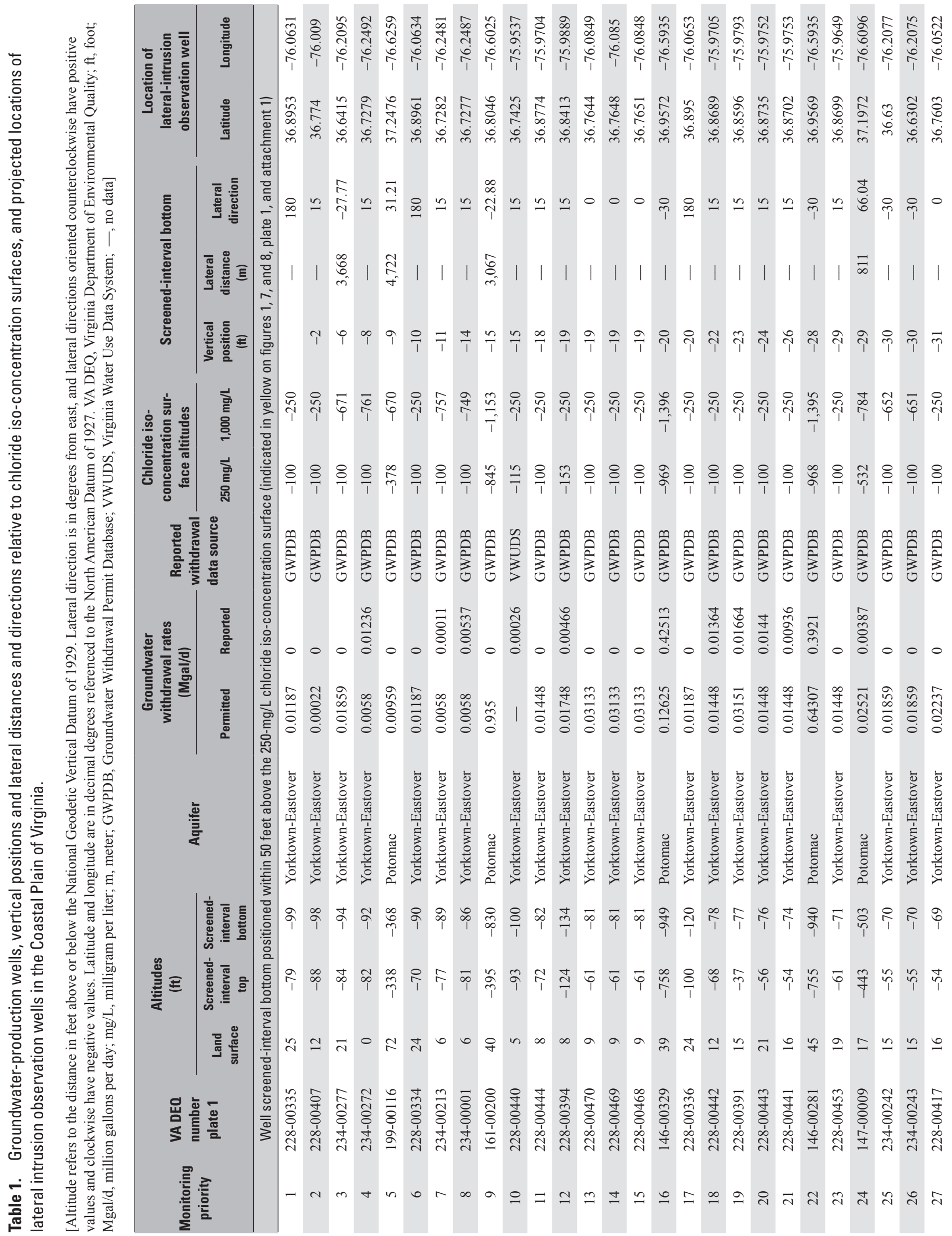




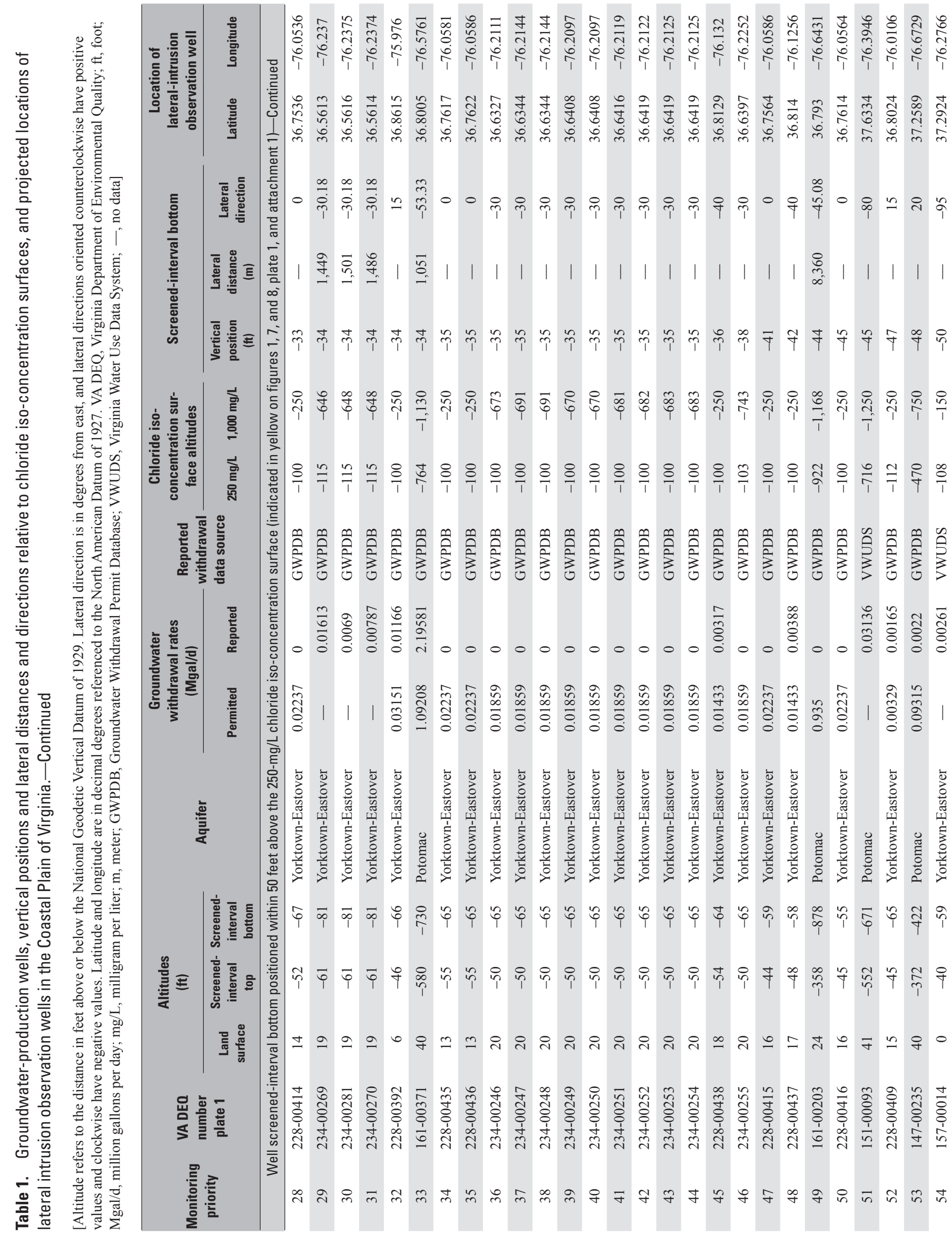




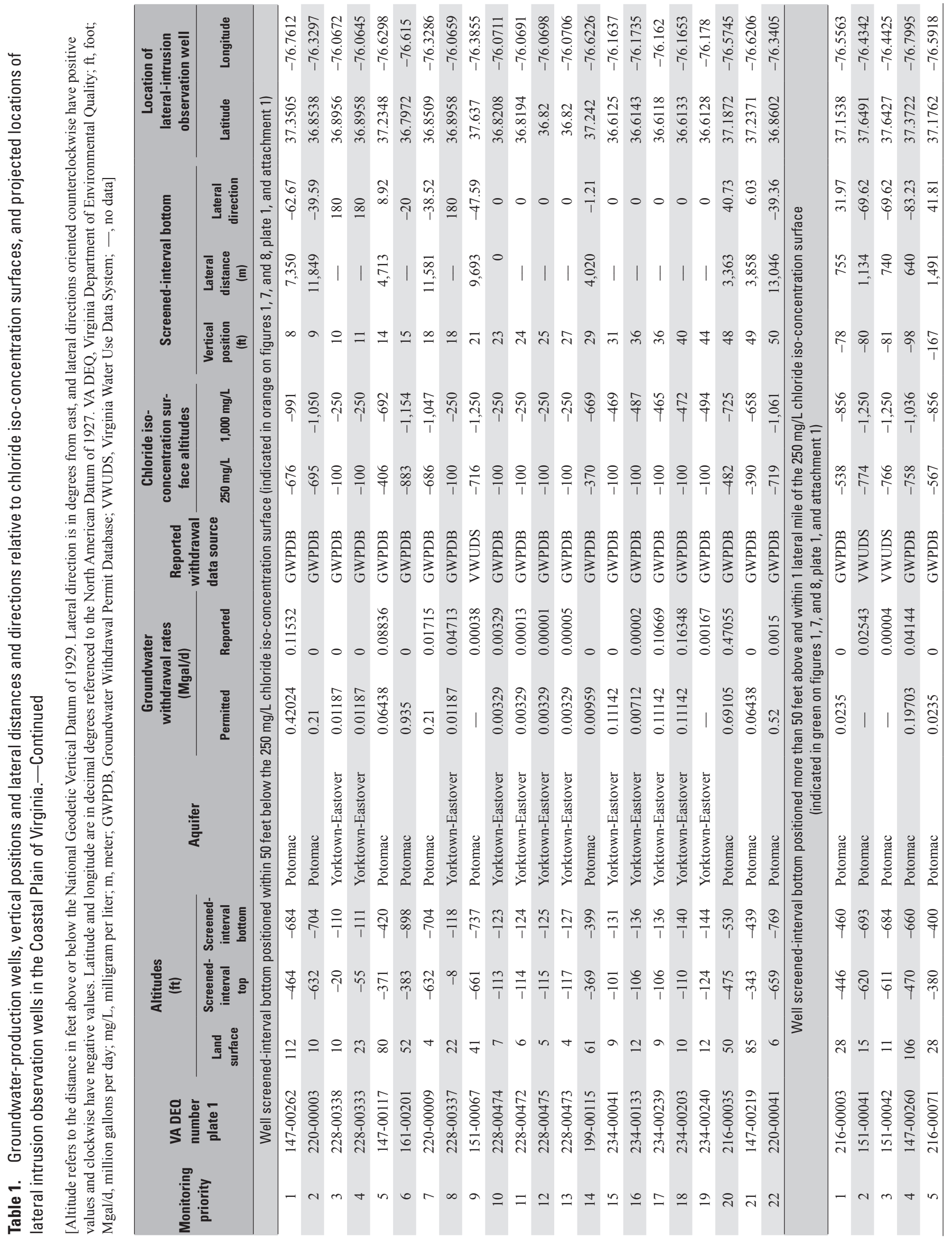


Manuscript approved August 21, 2015

Prepared by the USGS Science Publishing Network Edited by Rebekah Davis, Rolla PSC Illustrations and layout by Caryl J. Wipperfurth, Raleigh PSC

For more information concerning this report, contact: Director USGS Virginia Water Science Center 1730 East Parham Road

Richmond, VA 23228

(804) 261-2600

(804) 261-2657 fax

Or visit the Virginia Water Science Center Web site: http://va.water.usgs.gov/ 
